\title{
Menopause, obesity and inflammation: interactive risk factors for Alzheimer's disease
}

\author{
Amy Christensen and Christian J. Pike* \\ Davis School of Gerontology, University of Southern California, Los Angeles, CA, USA
}

Alzheimer's disease (AD) is a multifactorial neurodegenerative disorder, the development of which is regulated by several environmental and genetic risk factors. Two factors theorized to contribute to the initiation and/or progression of $A D$ pathogenesis are age-related increases in inflammation and obesity. These factors may be particularly problematic in women. The onset of menopause in mid-life elevates the vulnerability of women to $A D$, an increased risk that is likely associated with the depletion of estrogens. Menopause is also linked with an abundance of additional changes, including increased central adiposity and inflammation. Here, we review the current literature to explore the interactions between obesity, inflammation, menopause and AD.

Keywords: adiposity, aging, Alzheimer's disease, estrogen, hormone therapy, inflammation, obesity

\section{OPEN ACCESS}

Edited by: Paula I. Moreira,

University of Coimbra, Portugal

Reviewed by:

Ana I. Duarte,

University of Coimbra, Portugal Lucia Carboni,

Alma Mater Studiorum University of Bologna, Italy

*Correspondence:

Christian J. Pike,

Davis School of Gerontology, University of Southern California,

3715 McClintock Avenue, Los Angeles, CA 90089-0191, USA cjpike@usc.edu

Received: 03 May 2015 Accepted: 25 June 2015 Published: 07 July 2015

Citation:

Christensen A and Pike CJ (2015) Menopause, obesity and inflammation: interactive risk factors for Alzheimer's disease.

Front. Aging Neurosci. 7:130. doi: 10.3389/fnagi.2015.00130

\section{Introduction}

Alzheimer's disease (AD) is an age-related neurodegenerative disease that is the leading cause of dementia. The causal factor(s) that drives development and progression of the disease is still debated, though the primary agents are likely $\beta$-amyloid protein $(A \beta)$ and the microtubule associated protein tau (LaFerla, 2010; Morris et al., 2014). A $\beta$ is a small, soluble peptide normally found at low levels in brain and bodily fluids. Increased production and/or decreased clearance of $A \beta$ fosters its inherent ability to self-associate into neurotoxic oligomeric forms that become deposited in the brain parenchyma as plaques and in the cerebrovasculature as cerebral amyloid angiopathy (Mucke and Selkoe, 2012). Interestingly, genetic mutations that underlie familial $A D$ yield increased $A \beta$ production or its propensity to aggregate (Tanzi, 2012). Thus, given both the toxic nature of $A \beta$ and its genetic links to the disease, $\mathrm{A} \beta$ accumulation is widely theorized to be the key regulator of $\mathrm{AD}$ pathogenesis (Hardy and Higgins, 1992; Hardy, 2006). However, increasing evidence indicates an essential role of tau, which undergoes hyperphosphorylation resulting in the formation of neurofibrillary tangles, a hallmark of $\mathrm{AD}$ neuropathology found in many dead and dying neurons (Iqbal et al., 2010). Emerging evidence indicates that tau, like $\mathrm{A} \beta$, can be a potent pathogenic protein and that it is capable of spreading pathology in a prion-like manner (Bloom, 2014; Zempel and Mandelkow, 2014).

$\mathrm{AD}$ is more than just the accumulation of oligomeric and fibrillar $\mathrm{A} \beta$ and abnormally phosphorylated tau. The disease is characterized by many pathologic changes, including hypometabolism (Mosconi et al., 2008; Yao et al., 2011), blood-brain-barrier (BBB) disruption (Zlokovic, 2011), and glial activation (Mrak and Griffin, 2005; Prokop et al., 2013). Sporadic $\mathrm{AD}$, which is not driven by the genetic mutations in familial $\mathrm{AD}$ and represents the vast majority of cases, is likely to reflect the interactive effects of normal aging with numerous environmental risk factors and subtle genetic polymorphisms. In turn, these 
interactions cooperatively disrupt pathways that regulate $A \beta$, tau, and other $\mathrm{AD}$ pathologies. Thus, unraveling $\mathrm{AD}$ risk, and perhaps developing successful prevention and intervention strategies, will require understanding the interactions between aging and a set of risk factors.

Two important AD risk factors are obesity and inflammation. Obesity has increased at an alarming rate across westernized countries, with approximately $70 \%$ of the US adult population currently classified as either overweight or obese (Ogden et al., 2014). Elevated adiposity increases the risks of numerous conditions, including metabolic syndrome (McGill, 2014), hypertension (Rahmouni, 2014), cardiovascular disease (Rocha and Libby, 2009), and AD (Jayaraman and Pike, 2014). One consequence of obesity that may underlie its pathogenic roles is chronic inflammation, which is observed both in brain and systemically. Inflammation is independently associated with $\mathrm{AD}$ and numerous other age-related disorders (Michaud et al., 2013; Bettcher and Kramer, 2014). A wealth of genetic, epidemiological, and experimental findings identifies proinflammatory pathways as significant regulators of various $\mathrm{AD}$ pathologies (Wyss-Coray and Rogers, 2012). Interestingly, risk factors can affect men and women differently. For example, the apolipoprotein E $\varepsilon 4$ allele (ApoE4), the most significant genetic risk factor for late-onset $\mathrm{AD}$, affects women much more strongly than men (Altmann et al., 2014). The enhanced vulnerability of aging women to some conditions, including increased risk of osteoporosis, cardiovascular disease and perhaps $\mathrm{AD}$, is related to depletion of estrogens at menopause. Here, we consider the roles of obesity and inflammation in $\mathrm{AD}$ pathogenesis with a specific emphasis on women, who are disproportionately affected by $\mathrm{AD}$.

\section{$A D$ and Obesity}

Obesity is a precursor condition for numerous disorders, including cardiovascular disease, metabolic syndrome, and type 2 diabetes (T2D; Bonomini et al., 2015; Kim and Feldman, 2015). More recently, obesity and its associated comorbid conditions have been identified as significant risk factors for both cognitive decline and the development of AD (Jayaraman and Pike, 2014). A growing literature suggests that the insulin resistance and dysregulation of insulin signaling associated with $\mathrm{T} 2 \mathrm{D}$ are precursors to both cognitive impairment and $\mathrm{AD}$ (Yaffe et al., 2004; Profenno et al., 2010). T2D in humans has been shown to increase the rate of age-related mental decline (Hassing et al., 2004), and those with T2D have been shown to develop cognitive impairment earlier than those without this risk factor (Cigolle et al., 2011). Further, adults with T2D have a significantly increased risk of AD (Luchsinger et al., 2004; Biessels et al., 2006; Profenno et al., 2010). Similarly, obesity appears to significantly increase AD risk, particularly when it is present during middle age (Kivipelto et al., 2005; Beydoun et al., 2008; Fitzpatrick et al., 2009; Xu et al., 2011). In contrast to most of the literature, a recent study with a very large sample size reported that midlife obesity (measured as body mass index, $\mathrm{BMI}$ ) reduces dementia risk (Qizilbash et al., 2015). The absence of concordance among several well-controlled studies suggests that the relationship between obesity and $\mathrm{AD}$ is more complex than simply an increase in adiposity. For example, some studies suggest that dementia risk is not adversely affected by BMI per se, but rather by central obesity specifically (Whitmer et al., 2008; Gustafson et al., 2009; Luchsinger et al., 2012), which is often closely associated with adverse health effects including cardiovascular disease. In fact, cardiovascular outcomes are predicted better by measures of central obesity and often poorly by BMI (Yusuf et al., 2005; Dallongeville et al., 2012). Age is also an important consideration, as obesity in late life appears to reduce rather than increase AD risk (Fitzpatrick et al., 2009; Gustafson et al., 2009). Collectively, these observations suggest that central obesity in midlife induces changes that may create a neural environment conducive to initial development of $\mathrm{AD}$ pathology.

In general agreement with the human literature, experimental studies in mouse models of $\mathrm{AD}$ demonstrate that diet-induced obesity (DIO) significantly exacerbates AD-like neuropathology and worsens cognitive impairment (Julien et al., 2010; Herculano et al., 2013). Short-term high fat diet in an AD mouse model was shown to cause mild metabolic dysfunction and significant cognitive impairment, although no changes were observed in levels of $\mathrm{A} \beta$, a key protein in $\mathrm{AD}$ pathogenesis (Herculano et al., 2013). High fat and high sucrose diets have also been shown to affect tau accumulation, processing and hyperphosphorylation (Julien et al., 2010; Orr et al., 2014; Takalo et al., 2014). In $3 \times \mathrm{Tg}-\mathrm{AD}$ mice, longer-term administration of a high fat diet (16 weeks) impaired cognitive performance in both male and female mice (Barron et al., 2013). In line with the behavioral deficits, both male and female $3 \times$ Tg-AD mice showed increased $\mathrm{A} \beta$ burden in the hippocampus. Male and female non-transgenic rodents both exhibit decreased cognitive performance after exposure to high fat diet (Molteni et al., 2002; Farr et al., 2008; Granholm et al., 2008). In some cases, male mice are more vulnerable to diet-induced cognitive impairment (Hwang et al., 2010). Since males typically exhibit significantly more robust metabolic deficits in response to high-fat diets (Barron et al., 2013), this may suggest that some aspects of obesity-induced cognitive impairment are related to metabolic disturbances, including insulin resistance. However, since even short-term exposure (9 days) to diets high in fat (Murray et al., 2009) results in impaired spatial memory in rats, more immediate effects of diet must also contribute to cognitive deficits. Diets high in sugars can also yield negative outcomes in $\mathrm{AD}$ mouse models (Cao et al., 2007; Orr et al., 2014) and wild-type rats (Hsu et al., 2015). Together, these studies show that exposure to obesityinducing diets results in both rapid and long-term neural changes that impair cognitive performance and accelerate development of AD-like pathology.

The mechanism(s) by which obesity increases AD risk and cognitive deficits is unknown, although numerous possibilities have been proposed (Jayaraman et al., 2014). One widely discussed concept is that $\mathrm{AD}$ risk is linked with changes in glucose metabolism and insulin signaling (Blázquez et al., 2014; de la Monte and Tong, 2014). Consistent with this position, a reduction in brain glucose metabolism has been shown to be a preclinical symptom of AD (Mosconi, 2005). This reduction appears to be associated with altered insulin 
signaling. In obese patients, insulin resistance results in an elevated release of peripheral insulin, but insulin concentrations in the brain are reduced, likely due to a decrease in insulin transport across the BBB (Craft, 2007). Although insulin levels are decreased centrally, the situation is further exacerbated by altered insulin signaling in the brain that is less effective than under normal conditions (Anthony et al., 2006). Interestingly, intranasal administration of insulin has been shown to improve hippocampal dependent memory in patients with early stages of AD (Reger et al., 2008; Claxton et al., 2015). Perhaps in contrast to these observations, DIO in female $3 \times \mathrm{Tg}-\mathrm{AD}$ mice accelerated $\mathrm{A} \beta$ accumulation and behavioral impairment in the absence of apparent changes in peripheral insulin levels and sensitivity (Barron et al., 2013). Collectively, these data suggest that obesity-induced insulin resistance and/or impaired insulin signaling can contribute to $\mathrm{AD}$ neuropathology although additional factors also play significant roles.

Other than insulin-related deficits induced by obesity, increased adiposity has other systemic effects that may contribute to induction and progression of AD. For example, increased adiposity elevates neuroinflammation (Thaler and Schwartz, 2010; Thaler et al., 2012; Jayaraman et al., 2014; Aguilar-Valles et al., 2015), which has been implicated as a pathologic mechanism in AD (Johnston et al., 2011; Verri et al., 2012; Wyss-Coray and Rogers, 2012). Systemic and central inflammation will be discussed in greater detail below. However, cerebrovascular inflammation in particular has been widely associated with both obesity (Tucsek et al., 2014) and AD (Yu et al., 2012; Takeda et al., 2013). In fact, vascular inflammation may precede $\mathrm{AD}$, as a transgenic rodent model of obesity and $\mathrm{AD}$ showed cerebrovascular inflammation and cognitive deficits prior to the deposition of $A \beta$ (Takeda et al., 2010). In this model, cerebral amyloid angiopathy was much greater in obese animals compared to lean ones. Other vascular risk factors that are associated with obesity, including hyperlipidemia and hypertension, have also been identified as $\mathrm{AD}$ risk factors (Kivipelto et al., 2005). Thus, the mechanisms by which obesity increases $\mathrm{AD}$ risk are presumably multifactorial and likely modulated by a constellation of interactive risk factors and comorbidities.

\section{AD and Inflammation}

Although inflammation has been implicated in $\mathrm{AD}$ pathogenesis for many years, the importance of its role has been increasingly appreciated in the past few years. As has been discussed in other recent reviews (Mandrekar-Colucci and Landreth, 2010; Wyss-Coray and Rogers, 2012), multiple lines of evidence link inflammation as a key contributor to both the initiation and progression of $\mathrm{AD}$ and identify it as a compelling therapeutic target. Much of the recent focus on inflammation comes from the linkage to $\mathrm{AD}$ of polymorphisms in genes that are expressed by microglia and or play a role in innate immune responses (Tanzi, 2012). Included in this list are CD33 (Bertram et al., 2008; Hollingworth et al., 2011; Naj et al., 2011) and triggering receptor expressed on myeloid cells 2 (TREM2; Leavy, 2015), which are expressed in microglia and contribute to phagocytosis and $\mathrm{A} \beta$ clearance. Other immune-related factors linked to $\mathrm{AD}$ are CR1 and clusterin (Harold et al., 2009; Lambert et al., 2009), components of the complement system.

Microglia are the key mediators of neuroinflammation, functioning as the brain's resident macrophages. In their role as brain immune sentinels, microglia constantly survey the neural environment for both normal and pathological disruptions. In their normal state, microglia are clearly beneficial, utilizing phagocytosis to remove unwanted or unneeded materials and to regulate homeostatic processes such as synaptic remodeling (Chen and Trapp, 2015). Further, they may have important neurotrophic roles as suggested by their secretion of brainderived neurotrophic factor and insulin-like growth factor 1 (Parkhurst et al., 2013; Suh et al., 2013). When activated under more pathological conditions, microglia exhibit a wide range of responses that continue to be defined (Colton, 2009). Among these responses, microglia alter their phagocytic activities and can secrete large amounts of pro-inflammatory cytokines. Cytokine secretion can be aggravated when microglia are primed by an initial activating insult (Teeling and Perry, 2009). This type of priming response may contribute to interactions among comorbid conditions such as obesity. In this case, a high fat diet that results in obesity may represent the first hit on the microglia and $A \beta$ accumulation the second, yielding an exaggerated response that may drive pathology.

The AD brain is characterized by extensive gliosis, including activation and increased numbers of both astrocytes and microglia as well as elevated levels of inflammatory cytokines. $A \beta$ plaques, once formed, are rapidly (within 1-2 days) surrounded by microglia (Meyer-Luehmann et al., 2008). A $\beta$ has been shown to promote the release of inflammatory cytokines from microglia (Wyss-Coray and Rogers, 2012). Interestingly, increased proinflammatory factors can result in greater amyloid precursor protein production, leading to even more $A \beta$ release and creating a vicious cycle that further promotes $\mathrm{AD}$ pathology (Karran et al., 2011). This progression of pathology appears to yield multiple states of microglial activation and deactivation that presumably vary in their effects on discrete AD pathologies (Colton, 2009). For example, initial exposures of microglia to $A \beta$, while the microglia are in their resting anti-inflammatory state, can result in effective $A \beta$ clearance. However, this insult induces an activation state associated with the release of pro-inflammatory cytokines like tumor necrosis factor $\alpha(\mathrm{TNF} \alpha)$ and interleukin $1 \beta$ (IL-1 $\beta$ ). After microglia achieve a pro-inflammatory state, they may be less able to effectively phagocytose extracellular $\mathrm{A} \beta$ (Koenigsknecht-Talboo and Landreth, 2005). Similarly, microglia in an $\mathrm{AD}$ mouse model mice were shown to be anti-inflammatory early in the disease, but to be activated later after the pathology had progressed (Jimenez et al., 2008).

\section{Obesity and Inflammation}

It has been more than two decades since the link between inflammation and insulin resistance was first shown with an increase in TNF $\alpha$ levels in obese rodents (Hotamisligil et al., 
1993). Confirming an active rather than passive role in pathology, neutralization of $\mathrm{TNF} \alpha$ in obese rats resulted in a restored response to insulin. This and other early studies spawned intense study on the role of numerous inflammatory factors in obesity, metabolic syndrome, and T2D. It is now clear that not only is chronic low grade inflammation a symptom of metabolic disorders, but also that both peripheral (Hotamisligil, 2006) and central (Thaler and Schwartz, 2010) inflammation contribute to the development and progression of obesity and its comorbidities.

Visceral fat, also known as central or abdominal fat, is thought to have the greatest correlation with metabolic dysfunction (Kissebah et al., 1982; Nieves et al., 2003). An increase in body weight results in a corresponding increase in the number of mature macrophages found in adipose tissue. Macrophages invade and surround necrotic adipocytes and secrete excess pro- and anti-inflammatory cytokines, including $\mathrm{TNF} \alpha$ and interleukin 6 (IL-6). The release of proinflammatory cytokines by macrophages is thought to contribute to the glucose disruptions and insulin resistance that is seen in obese individuals. Indeed, if macrophages are specifically ablated, insulin and glucose homeostasis can be rapidly restored and levels of inflammatory cytokines in adipose tissue, muscle and serum reduced (Patsouris et al., 2008). Further, adipocytes themselves secrete leptin and IL- 6 after the macrophage infiltration and further increase the inflammatory response due in obesity. Adipose tissue is a highly active immunological organ that contributes to the increased inflammatory response to weight gain.

The role of inflammation in obesity also includes key contributions from the brain. Obesity-induced increases in peripheral and circulating cytokine levels likely affect the brain in multiple ways. However, available evidence suggests that central inflammation begins prior to the onset of obesity and appears to contribute to the process (Thaler et al., 2013). Much of the data on central inflammation and obesity has been generated from DIO paradigms, in which increased adiposity results from maintaining rodents on high-fat diets. DIO recapitulates much of the human obesity condition and can be modified to include specialized fats and/or sugars. Rodent DIO models have shown that both central and peripheral inflammation are induced with high fat diet (De Souza et al., 2005; Milanski et al., 2009; Thaler et al., 2012). Inflammation in the hypothalamus in response to high fat diet occurs within hours and persists for a few days before subsiding only to return after about 2 weeks (Thaler et al., 2012). Peripheral inflammation takes longer to develop and usually coincides with an increase in adipose tissue mass. Interestingly, mice with IL-1 $\beta$, IL-6, or TNF $\alpha$ receptor knocked out show a worsening rather than a reduction in both obesity and metabolic syndrome, suggesting that inflammation is not the only contributing factor to these afflictions.

Inflammatory cytokines, which are elevated by obesity in both adipose tissue and brain, appear to be involved in both promoting inflammation and mediating many of its deleterious effects. In the hypothalamus, DIO induces inflammation within 3 days of the initiation of high fat diet in rodent (Thaler et al., 2012). Shortterm high fat diet results in an upregulation of activated microglia and astrocytes. In humans, increased gliosis that is similar to that characteristic of injury is seen in the medial basal hypothalamus of obese patients (Thaler et al., 2012). Consistent with their role in adverse neural outcomes, cortical glia cultured from obese mice retain their inflammatory phenotype and impair neuron survival and growth in vitro (Jayaraman et al., 2014). Numerous inflammatory factors have been shown to be upregulated by obesity, including IL-1 $\beta$, IL-6, TNF $\alpha$ and interleukin 18 (IL-18; Vandanmagsar et al., 2011), but which ones are central the relationship between obesity and $\mathrm{AD}$ are unclear. Here, we consider a few of the factors that are affected by obesity with an emphasis on those that also have been implicated in AD.

\section{Leptin}

Leptin is an adipokine that modulates appetite and informs the brain about the availability of stored energy. Although leptin is thought of as a peptide hormone, it bears remarkable similarity to inflammatory cytokines, especially interleukin 2 (IL-2). Further, the leptin receptor is homologous to the type 1 cytokine receptors. Leptin secretion increases with increasing adiposity (Considine et al., 1996). In the hypothalamus, leptin regulates appetite. High levels of leptin normally induce satiety. However, obese individuals develop leptin resistance, attenuating its ability to properly regulate appetite. The increase in adipose tissue in obese individuals initially results in elevated leptin release, but the response to leptin is blunted and the satiety signal is not recognized. The mechanisms that underlie leptin resistance have not been fully elucidated, but it may be the result of disrupted leptin signaling pathways, decreased leptin transport across the $\mathrm{BBB}$, or increased inflammation in the hypothalamus (Park and Ahima, 2015).

In addition to regulating appetite, leptin is a regulator of inflammation and the immune system. Leptin regulates both innate and adaptive immune responses and generally increases levels of pro-inflammatory cytokines (Conde et al., 2014). Initial evidence of this link emerged from the observation that mice with deficiencies in leptin signaling $(o b / o b$ or $d b / d b)$ exhibit impaired immune responses (Lord et al., 1998). On the other hand, leptin exposure increases the proliferation and activation of T lymphocytes and promotes a T helper 1 phenotype (MartínRomero et al., 2000). Similarly, leptin activates components of the innate immune response. For example, leptin increases activation of monocytes, including their production of cytokines such as TNF $\alpha$ and IL-6 (Santos-Alvarez et al., 1999). Also, leptin can induce the expression of nitric oxide and prostaglandin estrogen $17 \beta$-estradiol (E2) in cultured macrophages (Raso et al., 2002). With signaling capacity both peripherally and centrally and release modulated by fat mass, leptin is well positioned to function as a mediator of interactions between the brain and peripheral inflammatory responses (Carlton et al., 2012), particularly in the context of obesity (Aguilar-Valles et al., 2015).

Leptin resistance is predicted to foster $\mathrm{AD}$ pathogenesis as normal leptin signaling is associated with reduced $\mathrm{AD}$ risk. Persons with mild cognitive impairment or $\mathrm{AD}$ show lower plasma levels of leptin than cognitively normal controls (Johnston et al., 2014). Cerebrospinal fluid (CSF) leptin levels can remain stable with progression to $\mathrm{AD}$, but a reduction in leptin signaling in hippocampus suggests $\mathrm{AD}$ is associated with 
attenuation of leptin actions (Maioli et al., 2015). Conversely, in a prospective study, elevated leptin levels were associated with greater cerebral brain volume and reduced dementia risk (Lieb et al., 2009). In experimental AD models, leptin administration has been shown to have therapeutic effects on both $\mathrm{A} \beta$ deposition (Fewlass et al., 2004) and tau phosphorylation (Greco et al., 2008). Such protective pathways may become dysfunctional in the $\mathrm{AD}$ brain, where leptin levels are elevated but expression of its receptor is downregulated (Bonda et al., 2014). Further, the leptin receptor protein was found localized to neurons containing neurofibrillary tangles and within plaques, a situation expected to disrupt its signaling capability. Indeed, phosphorylation of the leptin receptor, which is required for its activation, was reduced when the leptin receptor was found in tangle-bearing neurons (Bonda et al., 2014). Collectively, available data indicate that a loss of beneficial leptin signaling can contribute to $\mathrm{AD}$, suggesting that leptin resistance may be a mechanism by which obesity affects $\mathrm{AD}$ risk.

\section{TNF $\alpha$}

$\mathrm{TNF} \alpha$ appears to be produced exclusively by macrophages in adipose tissue with no contribution from adipocytes (Weisberg et al., 2003). Both $\mathrm{TNF} \alpha$ protein and mRNA are robustly upregulated in obesity, an increase that has been shown to correlate with the development of insulin resistance (Hotamisligil et al., 1995). An increase in abdominal adipose tissue in particular has been shown to correlate with increased TNF $\alpha$ release (Tsigos et al., 1999). After weight loss, a decrease in TNF $\alpha$ protein in adipose tissue and a decrease in serum insulin is observed (Hotamisligil et al., 1995).

The neural effects of $\mathrm{TNF} \alpha$, which is produced in brain by neurons and glia, can be both desirable and detrimental. Transiently elevated levels of TNF $\alpha$ are beneficial. For example, $\mathrm{TNF} \alpha$ can recruit astrocytes and microglia to sites of injury and activate a glial response (Flynn et al., 2003). However, $\mathrm{TNF} \alpha$ also exerts negative effects on neural plasticity, such as reducing levels of long-term potentiation (Beattie et al., 2002; Ferguson et al., 2008). Increased TNF $\alpha$ is also thought to promote $\mathrm{AD}$ pathogenesis. For instance, in vitro and in vivo evidence indicate that $\mathrm{TNF} \alpha$ increases $A \beta$ levels by increasing expression of BACE1, an enzyme that drives $\mathrm{A} \beta$ production (Yamamoto et al., 2007). Further, TNF $\alpha$ has been shown to inhibit the transport of $\mathrm{A} \beta$ out of the brain and into peripheral circulation where it can be eliminated (López et al., 2008). TNF $\alpha$-mediated increases in $A \beta$ can lead to a vicious cycle. $A \beta$ not only increases expression of TNFa (Meda et al., 1995; Akama and Van Eldik, 2000) but also is able to activate the TNF $\alpha$ receptor TNFRI, which is upregulated in $\mathrm{AD}$ brains compared to normal controls ( $\mathrm{Li}$ et al., 2004; Cheng et al., 2010). Further, A $\beta$-induced generation of TNF $\alpha$ is implicated in the neurotoxic effects of $A \beta$ (Xie et al., 2002). Conversely, reducing TNF $\alpha$ may be neuroprotective. For example, TNFRI knockout in $\mathrm{AD}$ transgenic mice diminishes AD-like neuropathology (He et al., 2007).

\section{IL-6}

Both adipocytes and macrophages can generate and secrete IL-6 from adipose tissue. Greater adiposity results in increased
IL-6 secretion. Serum IL-6 concentrations have been positively correlated with obesity, insulin resistance (Bastard et al., 2000; Kern et al., 2001), T2D (Pradhan et al., 2001), and cardiovascular disease (Plutzky, 2001). Multiple studies in both mice and humans have linked IL- 6 to T2D as the cytokine with the strongest association with metabolic dysfunction (Kern et al., 2001; Pradhan et al., 2001). Although IL-6 production is associated with visceral fat (Fontana et al., 2007), the relationship between IL- 6 and obesity is not straightforward. For example, IL-6 knockout mice develop obesity, elevated leptin, and altered glucose homeostasis with aging (Wallenius et al., 2002), suggesting that long-term IL-6 depletion can contribute to metabolic dysfunction. IL-6 administered peripherally in knockout mice, reduces body weight and leptin levels. However, IL-6 treatment is also associated with deleterious effects in several paradigms. For example, in mouse hepatocytes and a human hepatocarcinoma model, IL-6 disrupts insulin signaling by decreasing insulin's ability to activate Akt, a critical part of insulin's modulation of downstream metabolic effects (Senn et al., 2002).

As with several other pro-inflammatory cytokines, chronic elevation of IL-6 results in negative neural consequences. Crosssectional and longitudinal data indicate that elevated plasma IL-6 in mid-life is associated with significant cognitive decline (SinghManoux et al., 2014). Several IL-6 genetic variants have been shown to significantly regulate $\mathrm{AD}$ risk (Papassotiropoulos et al., 1999; Chen et al., 2012; Flex et al., 2014). IL-6 has consistently been shown to be elevated in the brains, especially near $A \beta$ plaques, and in the CSF of AD patients (Bauer et al., 1991; BlumDegen et al., 1995). The astrogliosis and microgliosis triggered by AD results in increased IL- 6 release from both of these cell types (Erta et al., 2012). IL-6 has been implicated in AD pathogenesis through several different mechanisms. For example, cultured cortical neurons show more damage when treated with both $\mathrm{A} \beta$ and IL-6. Further, in cultured hippocampal neurons, IL-6 has been shown to increase tau phosphorylation (Quintanilla et al., 2004).

\section{AD, Menopause and Hormone Therapy}

Since women are disproportionately affected by $\mathrm{AD}$, there has been considerable interest in understanding differences in estrogen across the lifespan associated with $\mathrm{AD}$ risk. One approach to investigating this idea is to consider the effects of pregnancies, which yield a net decrease in lifetime estrogen exposure (Bernstein et al., 1985; Hankinson et al., 1995). Several studies have shown that women who have birthed children are more likely to suffer from cognitive impairment and $\mathrm{AD}$ than nulliparous women (Ptok et al., 2002; McLay et al., 2003; Colucci et al., 2006; Beeri et al., 2009). Men with or without children show no change in $\mathrm{AD}$ risk, so the difference cannot be due to environmental factors associated with child rearing (Ptok et al., 2002). Nulliparous women are therefore seemingly protected from cognitive decline by their greater lifetime exposure to estrogens.

Another approach to address this issue is to consider the potential effects of estrogen loss on $\mathrm{AD}$ risk. Most studies have found that surgical menopause prior to the development 
of natural menopause significantly increases risks for cognitive decline and AD (Rocca et al., 2007, 2011; Phung et al., 2010; Bove et al., 2014). Conversely, oophorectomy after the age of natural menopause does not appear to significantly alter AD risk (Rocca et al., 2011; Imtiaz et al., 2014). The implication of these studies is that early loss of sex steroid hormones can accelerate the development of AD. However, although brain levels of estrogens are lower in women with $\mathrm{AD}$ than age-matched women without neurologic disease, this relationship has been reported for only for women older than age 80 years (Yue et al., 2005; Rosario et al., 2011). Thus, while low estrogen appears to be associated with $\mathrm{AD}$, the timing of this relationship with respect to disease onset remains unsettled.

If the depletion of ovarian sex steroid hormones at menopause is a risk factor for $\mathrm{AD}$, then maintenance of hormones would be predicted to reduce $\mathrm{AD}$ risk. Consistent with this idea, $\mathrm{AD}$ risk has been reported to be lowest in postmenopausal women with the highest endogenous E2 levels and greatest in those with low E2 levels (Manly et al., 2000). Another approach is to consider how AD risk is affected by treatment with estrogen-based HT. Initial observational studies generally found significantly reduced risk of $\mathrm{AD}$ in women with a history of hormone therapy (HT) use (Henderson et al., 1994, 1996), findings that were supported by subsequent prospective studies (Tang et al., 1996; Kawas et al., 1997; Zandi et al., 2002). Human studies have been mirrored by experiments in transgenic mouse models of $\mathrm{AD}$, in which ovariectomy (OVX) induced loss of sex steroid hormones increases and treatment with E2 generally reduces AD-like neuropathology (Zheng et al., 2002; Yue et al., 2005; Carroll et al., 2007; Zhao et al., 2011).

Despite the apparent benefits of estrogen-based HT in reducing $\mathrm{AD}$ risk, discrepant clinical findings have demonstrated neural risks and questioned its benefits. Most importantly, results of the Women's Health Initiative (WHI), a large double-blinded, placebo-controlled clinical trial, indicated increased rather than reduced dementia in subjects randomized to HT treatment (Shumaker et al., 2003, 2004). There are numerous factors that may contribute to the discordance of estrogen's benefits across the many human and rodent paradigms, including formulation of the treatment, continuous vs. discontinuous delivery, and route of administration. Perhaps the most significant issue is the timing of treatment, with initiation of HT near the onset of menopause hypothesized to be critical for its neural efficacy (Maki, 2006). In the WHI, the mean age of subjects was about 65 years old, many years past the average onset of menopause at age 51. Studies in which HT was initiated at or near menopause have generally reported benefits rather than risks. For example, in a Danish study in which middle aged women were randomized to HT and placebo treatment groups, beneficial effects on cognitive function were observed more than 10 years after the cessation of the 2-3 year HT regimen (Bagger et al., 2005). This finding suggests that using HT, even for a short time during menopause, may have a positive effect on cognition much later. Similar results have been found for $\mathrm{AD}$ risk: $\mathrm{HT}$ is associated with decreased risk if delivered near menopause but has no benefit or even increases risk when started several years after menopause (Henderson et al., 2005; Whitmer et al., 2011; Shao et al., 2012). More work will be required to fully elucidate the relationship between HT and $\mathrm{AD}$ risk, but emerging results seem to suggest that shortterm HT near menopause onset may offer a reasonable strategy to impede development of dementia.

Efficacy of HT is also likely to be modulated by genetic factors. The most significant genetic risk factor for late-onset $\mathrm{AD}$ is the $\varepsilon 4$ allele of ApoE4. ApoE4 regulates lipid trafficking and may play a role in the removal of $A \beta$ from the brain (Näslund et al., 1995; Leduc et al., 2011). HT may be differentially effective in women based on their ApoE status. In mice, E2 is able to reduce inflammatory markers in cultures from ApoE3, but not ApoE4 mice (Brown et al., 2008). One study showed that HT around menopause is more effective in preventing cognitive decline in ApoE4-negative women than those with even a single ApoE4 allele (Yaffe et al., 2000). Further, the ApoE4 genotype may increase the risk of $\mathrm{AD}$ more in females than males (Farrer et al., 1997; Bretsky et al., 1999). Increased AD risk in ApoE4 carriers requires only one ApoE4 allele in females with no further risk increase in homozygotes, whereas significant male risk appears to require two ApoE4 copies (Payami et al., 1996). A more recent study showed that both male and female ApoE4 carriers were at greater risk of $\mathrm{AD}$ with even one $\mathrm{ApoE} 4$ allele, but that the risk for female carriers was significantly greater (Altmann et al., 2014). How interactions between ApoE, HT and AD are modulated by obesity, inflammation, and other factors that drive $\mathrm{AD}$ pathogenesis remains to be determined.

\section{Menopause and Adiposity}

The shift from young adulthood into middle age is associated with increasing proportions of women that are overweight and/or obese (Ogden et al., 2014). This weight gain likely reflects multifaceted consequences of aging. There is evidence that depletion of sex steroid hormones during menopause can contribute to weight gain, although body weight also predicts subsequent changes in hormone levels (Guthrie et al., 1999; Sternfeld et al., 2004; Wildman et al., 2012). Significant increases in central fat have been reported with greater waist circumference after the last menstrual period (Poehlman et al., 1995; Björkelund et al., 1996; Ho et al., 2010). This increase in adiposity associated with menopause is linked with increased risks for obesity (Rachoń and Teede, 2010), metabolic syndrome (Carr, 2003; Cho et al., 2008) and T2D (Wajchenberg, 2000). Although increasing age may partially account for the increase T2D incidence in postmenopausal women (Janssen et al., 2008), the change in fat distribution has also been shown to be a contributing cause (Barrett-Connor et al., 1996; Tchernof et al., 1998; Sites et al., 2000).

Studies in both humans (menopause) and rodents (reproductive senescence) indicate that age-related ovarian hormone loss contributes to changes in the distribution of adipose tissue. The significant decrease in estrogen and progesterone that results from follicular depletion yields a more androgenic pattern of fat distribution-an increase in central or abdominal adiposity. OVX in mice, a model of surgical menopause, can result in a significant increase in body weight (Stubbins et al., 2012). This elevated weight results from a decrease in energy expenditure, as opposed to increases in 
calorie consumption, and promotes insulin resistance, increased adipocyte size, and peripheral inflammation (Rogers et al., 2009). Treatment of mice with the E2 results in reductions in all of these outcomes.

In postmenopausal women, estrogen-based HT has been shown to decrease some of these metabolic effects in addition to restoring a more gynoid pattern of fat distribution (BarrettConnor et al., 1996; Salpeter et al., 2006). HT can attenuate central adiposity when administered to early postmenopausal women (Haarbo et al., 1991; Ahtiainen et al., 2012). Additionally, HT may decrease total weight gain during menopause, especially in non-obese women (Kristensen et al., 1999). Further, HT has been shown to increase the effectiveness of concurrent lifestyle and pharmaceutical treatments for some obesity-related comorbidities (Golden et al., 2013).

The mechanisms by which E2 reduces obesity and risk of T2D remain to be fully elucidated. Paradoxically, risk of maternal insulin resistance is highest in late pregnancy when E2 levels are high (Ryan and Enns, 1988), yet low E2 levels after menopause have been linked with T2D (Carr, 2003; Meyer et al., 2011). Aromatase knockout mice, which cannot synthesize E2, are obese and insulin resistant (Jones et al., 2000). Estrogen receptor $\alpha(E R \alpha)$ is likely to play a role in regulation of obesity as $\mathrm{ER} \alpha$ knockout mice are more obese and glucose intolerant than wild-type females (Heine et al., 2000; Bryzgalova et al., 2006). Further, both peripheral and central E2 administrations have been shown to act through different pathways with similar overall outcomes of reductions in insulin resistance, glucose dysregulation and adiposity (Yonezawa et al., 2012). Peripheral and central E2 administration resulted in decreased adipocyte size and reduced expression of macrophage markers, although peripheral E2 treatment elicited greater changes. Only peripheral E2 administration decreased adipose expression of the pro-inflammatory cytokine TNF $\alpha$. Central and peripheral E2 administration both increased energy expenditure, but central E2 caused much greater spontaneous locomotor activity. Thus, E2 likely regulates adiposity and metabolic outcomes by actions on several tissues. How these actions are affected by aging likely underlies the interactions between menopause, obesity and the efficacy of HT.

\section{Inflammation and Menopause}

There are extensive literatures on the relationships between estrogens and other sex steroid hormones and regulation of inflammation. In general, one can reasonably argue that estrogens function as potent anti-inflammatory factors. Thus, depletion of E2 at menopause results in elevated proinflammatory cytokines and may place tissues throughout the body at increased risk of inflammation and diseases associated with inflammation (Pfeilschifter et al., 2002). However, this is an extensive and complex literature as estrogens regulate several aspects of immune function and inflammation (Straub, 2007) and thus can protect against some conditions but promote others (Gilliver, 2010). The relationships between estrogens, menopause, and inflammation-related disorders have been well described in numerous reviews for several conditions, including cardiovascular disease (Camilleri et al., 2012; Knowlton and
Lee, 2012), osteoarthritis (Martín-Millán and Castañeda, 2013), and rheumatoid arthritis (Islander et al., 2011). Thus, although estrogens can be broadly defined as anti-inflammatory, the effects of estrogen loss and estrogen-based HT depend upon the tissue, cell type, and context.

How menopause affects neuroinflammation has not been well studied. However, as with other tissues, the brain exhibits a generally pro-inflammatory phenotype with increasing age. In a study that examined changes in gene expression across age in adult human brain, male and female brains exhibited significant differences in the number of genes changing expression (higher in males), the patterns of changes in terms of gene function, and the brain region-specific nature of the changes (Berchtold et al., 2008). Of particular interest to the current topic, women exhibited greater proportional age-related increases in expression of genes associated with immune and inflammatory functions. Further, both women and men showed increased expression of these genes in hippocampus and entorhinal cortex (both of which are strongly affected in AD), but only women had significant increases in other brain regions (Berchtold et al., 2008), suggesting a more global pro-inflammatory condition in the aging female brain.

Like the human brain, the rodent female brain shows increased inflammation with aging that is regulated, in part, by estrogen status. For example, the frontal cortex of middle-aged female rats shows increased expression of several microglial and immune function genes as a consequence of both aging and estrogen-deprivation (Sárvári et al., 2012). Importantly, the authors also found a strongly overlapping pattern of gene expression changes in the frontal cortex of older postmenopausal women relative to younger premenopausal women. Confirming a protective role of estrogens, treatment of OVX middle-aged rats with E2 or ER-specific agonists significantly decreased expression of several microglial and immune function genes in the frontal cortex (Sárvári et al., 2011). This relationship extends to pro-inflammatory cytokines such as TNF $\alpha$ and IL-1 $\beta$, which show increased hippocampal expression in female mice as consequences of both aging and OVX-induced estrogen depletion (Benedusi et al., 2012). The age-related increase in the pro-inflammatory state of the brain can be exacerbated by inflammatory challenges. For example, the increased hippocampal expression of cytokines induced by high cholesterol diet is significantly worsened in reproductively senescent female rats, an effect that can be attenuated by estradiol treatment (Lewis et al., 2010). However, the ability of E2 to protect against elevated cytokine levels can significantly diminish, and in some cases reverse, in aged female brain (Nordell et al., 2003). Collectively, these observations indicate that both aging and menopause contribute to increasing levels of neuroinflammation, which are predicted to cooperatively interact in the promotion of inflammation neural diseases such as AD.

\section{Conclusion}

$\mathrm{AD}$ neuropathology is characterized and likely driven by the accumulation of $A \beta$ and abnormally phosphorylated tau. The development of these and other components of $\mathrm{AD}$ 


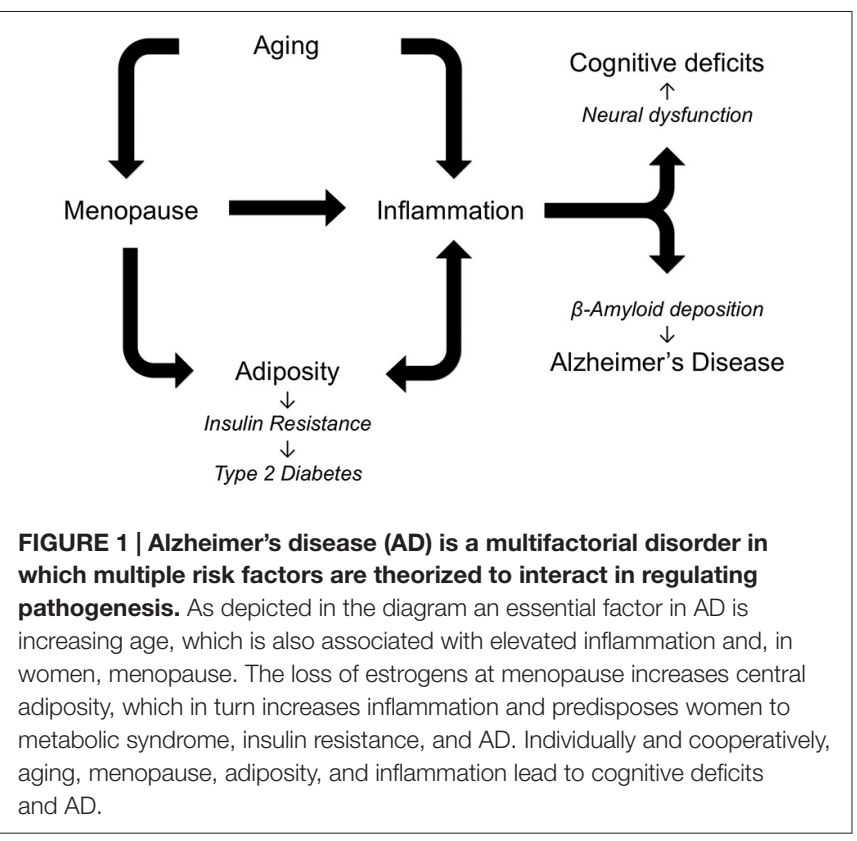

neuropathology result from the interactive effects of several risk factors (Figure 1). Most importantly, AD is dependent upon aging. The negative outcomes of all genetic and environmental risk factors of $\mathrm{AD}$ require advancing age. In women, chronological aging is also tied to reproductive aging that is manifested as menopause in mid-life. Menopause results in cessation of the ovarian cycle and its cyclical production of estrogens and progesterone, sex steroid hormones with numerous protective roles against AD (Pike et al., 2009). Beyond protective actions against specific aspects of $\mathrm{AD}$ neuropathology, estrogens function throughout the body to guard against the development of increasing central adiposity and inflammation, both of which are implicated in the initiation and progression of $\mathrm{AD}$. Of course, aging is also associated with significant increases in inflammation and central obesity, independent of estrogen levels. Thus, women are simultaneously exposed to the consequences of both chronological and reproductive aging, both of which can function as drivers of $\mathrm{AD}$, obesity, and inflammation.

\section{References}

Aguilar-Valles, A., Inoue, W., Rummel, C., and Luheshi, G. N. (2015). Obesity, adipokines and neuroinflammation. Neuropharmacology 96, 124-134. doi: 10. 1016/j.neuropharm.2014.12.023

Ahtiainen, M., Alen, M., Pöllänen, E., Pulkkinen, S., Ronkainen, P. H., Kujala, U. M., et al. (2012). Hormone therapy is associated with better body composition and adipokine/glucose profiles: a study with monozygotic co-twin control design. Menopause 19, 1329-1335. doi: 10.1097/gme. 0b013e31825a3344

Akama, K. T., and Van Eldik, L. J. (2000). Beta-amyloid stimulation of inducible nitric-oxide synthase in astrocytes is interleukin-1beta- and tumor necrosis factor-alpha (TNFalpha)-dependent and involves a TNFalpha receptorassociated factor- and NFkappaB-inducing kinase-dependent signaling mechanism. J. Biol. Chem. 275, 7918-7924. doi: 10.1074/jbc.275.11.7918
Estrogen-based HT initiated prior to the end of menopause has been shown to be effective in combating both the increased adiposity and the cognitive decline associated with aging. Although HT can exhibit adverse side effects, especially in those women who may be predisposed, emerging results suggest that relatively short-term HT initiated near the onset of menopause is likely to yield largely beneficial effects for most women. Much more research will need to be done to determine precisely which genetic or environmental factors define the target population.

Inflammation is another seemingly invariant consequence of aging. In females, inflammation is further increased by the loss of estrogens at menopause. As with many other age-related diseases, $\mathrm{AD}$ is linked with elevated inflammation during aging by abundant data from several fields. Several specific inflammatory factors have been linked to both obesity and $\mathrm{AD}$ including leptin, TNF- $\alpha$ and IL-6. Since estrogens protect against both the development and deleterious consequences of inflammation across many tissues, depletion of estrogens at menopause is theorized to contribute to women's vulnerability to AD. Agerelated increases in adiposity and changes in the distribution of fat to central depots further increase the risk of obesity, which promotes downstream conditions including insulin resistance, metabolic syndrome and T2D. Thus, a highly interactive set of relationships develops in women: the cumulative effects of aging, menopause, adiposity, and inflammation result in increased risk for neural dysfunction and $\mathrm{AD}$ pathogenesis (Figure 1). Certainly this set of factors is incomplete, as new data continue to identify additional factors, including bioenergetics, that not only are altered during reproductive aging but also can promote AD (Yin et al., 2015). Continued research is needed to address many unresolved issues about these pathological interactions, including how they are modified by genetic risk factors such as Apolipoprotein E (ApoE) and the extent to which they can be effectively attenuated by estrogenbased HT.

\section{Acknowledgments}

This work was supported by NIH grant AG026572 (RD Brinton and CJP/Project 3).

Altmann, A., Tian, L., Henderson, V. W., Greicius, M. D., and Alzheimer's Disease Neuroimaging Initiative Investigators. (2014). Sex modifies the APOErelated risk of developing Alzheimer disease. Ann. Neurol. 75, 563-573. doi: 10. 1002/ana.24135

Anthony, K., Reed, L. J., Dunn, J. T., Bingham, E., Hopkins, D., Marsden, P. K., et al. (2006). Attenuation of insulin-evoked responses in brain networks controlling appetite and reward in insulin resistance: the cerebral basis for impaired control of food intake in metabolic syndrome? Diabetes 55, 2986-2992. doi: 10.2337/db06-0376

Bagger, Y. Z., Tankó, L. B., Alexandersen, P., Qin, G., Christiansen, C., and PERF Study Group. (2005). Early postmenopausal hormone therapy may prevent cognitive impairment later in life. Menopause 12, 12-17. doi: 10. 1097/00042192-200512010-00005

Barrett-Connor, E., Schrott, H. G., Greendale, G., Kritz-Silverstein, D., Espeland, M. A., Stern, M. P., et al. (1996). Factors associated with glucose and insulin 
levels in healthy postmenopausal women. Diabetes Care 19, 333-340. doi: 10. 2337/diacare.19.4.333

Barron, A. M., Rosario, E. R., Elteriefi, R., and Pike, C. J. (2013). Sex-specific effects of high fat diet on indices of metabolic syndrome in $3 \times \mathrm{Tg}-\mathrm{AD}$ mice: implications for Alzheimer's disease. PLoS One 8:e78554. doi: 10.1371/journal. pone. 0078554

Bastard, J. P., Jardel, C., Bruckert, E., Blondy, P., Capeau, J., Laville, M., et al. (2000). Elevated levels of interleukin 6, are reduced in serum and subcutaneous adipose tissue of obese women after weight loss. J. Clin. Endocrinol. Metab. 85, 3338-3342. doi: 10.1210/jc.85.9.3338

Bauer, J., Strauss, S., Schreiter-Gasser, U., Ganter, U., Schlegel, P., Witt, I., et al. (1991). Interleukin-6 and alpha-2-macroglobulin indicate an acute-phase state in Alzheimer's disease cortices. FEBS Lett. 285, 111-114. doi: 10.1016/00145793(91)80737-n

Beattie, M. S., Hermann, G. E., Rogers, R. C., and Bresnahan, J. C. (2002). Cell death in models of spinal cord injury. Prog. Brain Res. 137, 37-47. doi: 10. 1016/s0079-6123(02)37006-7

Beeri, M. S., Rapp, M., Schmeidler, J., Reichenberg, A., Purohit, D. P., Perl, D. P., et al. (2009). Number of children is associated with neuropathology of Alzheimer's disease in women. Neurobiol. Aging 30, 1184-1191. doi: 10.1016/j. neurobiolaging.2007.11.011

Benedusi, V., Meda, C., Della Torre, S., Monteleone, G., Vegeto, E., and Maggi, A. (2012). A lack of ovarian function increases neuroinflammation in aged mice. Endocrinology 153, 2777-2788. doi: 10.1210/en.2011-1925

Berchtold, N. C., Cribbs, D. H., Coleman, P. D., Rogers, J., Head, E., Kim, R., et al. (2008). Gene expression changes in the course of normal brain aging are sexually dimorphic. Proc. Natl. Acad. Sci. U S A 105, 15605-15610. doi: 10. 1073/pnas.0806883105

Bernstein, L., Pike, M. C., Ross, R. K., Judd, H. L., Brown, J. B., and Henderson, B. E. (1985). Estrogen and sex hormone-binding globulin levels in nulliparous and parous women. J. Natl. Cancer Inst. 74, 741-745.

Bertram, L., Lange, C., Mullin, K., Parkinson, M., Hsiao, M., Hogan, M. F., et al. (2008). Genome-wide association analysis reveals putative Alzheimer's disease susceptibility loci in addition to APOE. Am. J. Hum. Genet. 83, 623-632. doi: 10. 1016/j.ajhg.2008.10.008

Bettcher, B. M., and Kramer, J. H. (2014). Longitudinal inflammation, cognitive decline and Alzheimer's disease: a mini-review. Clin. Pharmacol. Ther. 96, 464-469. doi: 10.1038/clpt.2014.147

Beydoun, M. A., Lhotsky, A., Wang, Y., Dal Forno, G., An, Y., Metter, E. J., et al. (2008). Association of adiposity status and changes in early to mid-adulthood with incidence of Alzheimer's disease. Am. J. Epidemiol. 168, 1179-1189. doi: 10.1093/aje/kwn229

Biessels, G. J., De Leeuw, F. E., Lindeboom, J., Barkhof, F., and Scheltens, P. (2006). Increased cortical atrophy in patients with Alzheimer's disease and type 2, diabetes mellitus. J. Neurol. Neurosurg. Psychiatry 77, 304-307. doi: 10. 1136/jnnp.2005.069583

Björkelund, C., Lissner, L., Andersson, S., Lapidus, L., and Bengtsson, C. (1996). Reproductive history in relation to relative weight and fat distribution. Int. J. Obes. Relat. Metab. Disord. 20, 213-219.

Blázquez, E., Velázquez, E., Hurtado-Carneiro, V., and Ruiz-Albusac, J. M. (2014). Insulin in the brain: its pathophysiological implications for states related with central insulin resistance, type 2, diabetes and Alzheimer's disease. Front. Endocrinol. (Lausanne) 5:161. doi: 10.3389/fendo.2014.00161

Bloom, G. S. (2014). Amyloid- $\beta$ and tau: the trigger and bullet in Alzheimer disease pathogenesis. JAMA Neurol. 71, 505-508. doi: 10.1001/jamaneurol. 2013.5847

Blum-Degen, D., Müller, T., Kuhn, W., Gerlach, M., Przuntek, H., and Riederer, P. (1995). Interleukin-1 beta and interleukin- 6 are elevated in the cerebrospinal fluid of Alzheimer's and de novo Parkinson's disease patients. Neurosci. Lett. 202, 17-20. doi: 10.1016/0304-3940(95)12192-7

Bonda, D. J., Stone, J. G., Torres, S. L., Siedlak, S. L., Perry, G., Kryscio, R., et al. (2014). Dysregulation of leptin signaling in Alzheimer disease: evidence for neuronal leptin resistance. J. Neurochem. 128, 162-172. doi: 10.1111/ jnc. 12380

Bonomini, F., Rodella, L. F., and Rezzani, R. (2015). Metabolic syndrome, aging and involvement of oxidative stress. Aging Dis. 6, 109-120. doi: 10.14336/ad. 2014.0305

Bove, R., Secor, E., Chibnik, L. B., Barnes, L. L., Schneider, J. A., Bennett, D. A., et al. (2014). Age at surgical menopause influences cognitive decline and Alzheimer pathology in older women. Neurology 82, 222-229. doi: 10 1212/WNL.0000000000000033

Bretsky, P. M., Buckwalter, J. G., Seeman, T. E., Miller, C. A., Poirier, J., Schellenberg, G. D., et al. (1999). Evidence for an interaction between apolipoprotein E genotype, gender and Alzheimer disease. Alzheimer Dis. Assoc. Disord. 13, 216-221. doi: 10.1097/00002093-199910000-00007

Brown, C. M., Choi, E., Xu, Q., Vitek, M. P., and Colton, C. A. (2008). The APOE4 genotype alters the response of microglia and macrophages to 17beta-estradiol. Neurobiol. Aging 29, 1783-1794. doi: 10.1016/j.neurobiolaging.2007.04.018

Bryzgalova, G., Gao, H., Ahren, B., Zierath, J. R., Galuska, D., Steiler, T. L., et al. (2006). Evidence that oestrogen receptor-alpha plays an important role in the regulation of glucose homeostasis in mice: insulin sensitivity in the liver. Diabetologia 49, 588-597. doi: 10.1007/s00125-005-0105-3

Camilleri, G., Borg, M., Brincat, S., Schembri-Wismayer, P., Brincat, M., and Calleja-Agius, J. (2012). The role of cytokines in cardiovascular disease in menopause. Climacteric 15, 524-530. doi: 10.3109/13697137.2012.700743

Cao, D., Lu, H., Lewis, T. L., and Li, L. (2007). Intake of sucrose-sweetened water induces insulin resistance and exacerbates memory deficits and amyloidosis in a transgenic mouse model of Alzheimer disease. J. Biol. Chem. 282, 36275-36282. doi: 10.1074/jbc.m703561200

Carlton, E. D., Demas, G. E., and French, S. S. (2012). Leptin, a neuroendocrine mediator of immune responses, inflammation and sickness behaviors. Horm. Behav. 62, 272-279. doi: 10.1016/j.yhbeh.2012.04.010

Carr, M. C. (2003). The emergence of the metabolic syndrome with menopause. J. Clin. Endocrinol. Metab. 88, 2404-2411. doi: 10.1210/jc.2003-030242

Carroll, J. C., Rosario, E. R., Chang, L., Stanczyk, F. Z., Oddo, S., LaFerla, F. M., et al. (2007). Progesterone and estrogen regulate Alzheimer-like neuropathology in female 3xTg-AD mice. J. Neurosci. 27, 13357-13365. doi: 10. 1523/jneurosci.2718-07.2007

Chen, S. Y., Chen, T. F., Lai, L. C., Chen, J. H., Sun, Y., Wen, L. L., et al. (2012). Sequence variants of interleukin 6, (IL-6) are significantly associated with a decreased risk of late-onset Alzheimer's disease. J. Neuroinflammation 9:21. doi: 10.1186/1742-2094-9-21

Chen, Z., and Trapp, B. D. (2015). Microglia and neuroprotection. J. Neurochem. doi: 10.1111/jnc.13062 [Epub ahead of print].

Cheng, X., Yang, L., He, P., Li, R., and Shen, Y. (2010). Differential activation of tumor necrosis factor receptors distinguishes between brains from Alzheimer's disease and non-demented patients. J. Alzheimers Dis. 19, 621-630. doi: 10. 3233/JAD-2010-1253

Cho, G. J., Lee, J. H., Park, H. T., Shin, J. H., Hong, S. C., Kim, T., et al. (2008). Postmenopausal status according to years since menopause as an independent risk factor for the metabolic syndrome. Menopause 15, 524-529. doi: 10. 1097/gme.0b013e3181559860

Cigolle, C. T., Lee, P. G., Langa, K. M., Lee, Y. Y., Tian, Z., and Blaum, C. S. (2011). Geriatric conditions develop in middle-aged adults with diabetes. J. Gen. Intern. Med. 26, 272-279. doi: 10.1007/s11606-010-1510-y

Claxton, A., Baker, L. D., Hanson, A., Trittschuh, E. H., Cholerton, B., Morgan, A., et al. (2015). Long-acting intranasal insulin detemir improves cognition for adults with mild cognitive impairment or early-stage Alzheimer's disease dementia. J. Alzheimers Dis. 44, 897-906. doi: 10.3233/JAD-141791

Colton, C. A. (2009). Heterogeneity of microglial activation in the innate immune response in the brain. J. Neuroimmune Pharmacol. 4, 399-418. doi: 10 1007/s11481-009-9164-4

Colucci, M., Cammarata, S., Assini, A., Croce, R., Clerici, F., Novello, C., et al. (2006). The number of pregnancies is a risk factor for Alzheimer's disease. Eur. J. Neurol. 13, 1374-1377. doi: 10.1111/j.1468-1331.2006.01520.x

Conde, J., Scotece, M., Abella, V., López, V., Pino, J., Gómez-Reino, J. J., et al. (2014). An update on leptin as immunomodulator. Expert Rev. Clin. Immunol. 10, 1165-1170. doi: 10.1586/1744666x.2014.942289

Considine, R. V., Sinha, M. K., Heiman, M. L., Kriauciunas, A., Stephens, T. W., Nyce, M. R., et al. (1996). Serum immunoreactive-leptin concentrations in normal-weight and obese humans. N. Engl. J. Med. 334, 292-295. doi: 10. 1056/NEJM199602013340503

Craft, S. (2007). Insulin resistance and Alzheimer's disease pathogenesis: potential mechanisms and implications for treatment. Curr. Alzheimer Res. 4, 147-152. doi: 10.2174/156720507780362137

Dallongeville, J., Bhatt, D. L., Steg, P. H., Ravaud, P., Wilson, P. W., Eagle, K. A., et al. (2012). Relation between body mass index, waist circumference and cardiovascular outcomes in 19,579 diabetic patients with established vascular 
disease: the REACH registry. Eur. J. Prev. Cardiol. 19, 241-249. doi: 10. $1177 / 1741826710394305$

de la Monte, S. M., and Tong, M. (2014). Brain metabolic dysfunction at the core of Alzheimer's disease. Biochem. Pharmacol. 88, 548-559. doi: 10.1016/j.bcp. 2013.12.012

De Souza, C. T., Araujo, E. P., Bordin, S., Ashimine, R., Zollner, R. L., Boschero, A. C., et al. (2005). Consumption of a fat-rich diet activates a proinflammatory response and induces insulin resistance in the hypothalamus. Endocrinology 146, 4192-4199. doi: 10.1210/en.2004-1520

Erta, M., Quintana, A., and Hidalgo, J. (2012). Interleukin-6, a major cytokine in the central nervous system. Int. J. Biol. Sci. 8, 1254-1266. doi: 10.7150/ijbs.4679

Farr, S. A., Yamada, K. A., Butterfield, D. A., Abdul, H. M., Xu, L., Miller, N. E., et al. (2008). Obesity and hypertriglyceridemia produce cognitive impairment. Endocrinology 149, 2628-2636. doi: 10.1210/en.2007-1722

Farrer, L. A., Cupples, L. A., Haines, J. L., Hyman, B., Kukull, W. A., Mayeux, R., et al. (1997). Effects of age, sex and ethnicity on the association between apolipoprotein E genotype and Alzheimer diseaseA meta-analysis. APOE and Alzheimer disease meta analysis consortium. J.AMA 278, 1349-1356. doi: 10. 1001/jama.1997.03550160069041

Ferguson, A. R., Christensen, R. N., Gensel, J. C., Miller, B. A., Sun, F., Beattie, E. C., et al. (2008). Cell death after spinal cord injury is exacerbated by rapid TNF alpha-induced trafficking of GluR2-lacking AMPARs to the plasma membrane. J. Neurosci. 28, 11391-11400. doi: 10.1523/JNEUROSCI.3708-08. 2008

Fewlass, D. C., Noboa, K., Pi-Sunyer, F. X., Johnston, J. M., Yan, S. D., and Tezapsidis, N. (2004). Obesity-related leptin regulates Alzheimer's Abeta. FASEB J. 18, 1870-1878. doi: 10.1096/fj.04-2572com

Fitzpatrick, A. L., Kuller, L. H., Lopez, O. L., Diehr, P., O’Meara, E. S., Longstreth, W. T., et al. (2009). Midlife and late-life obesity and the risk of dementia: cardiovascular health study. Arch. Neurol. 66, 336-342. doi: 10. 1001/archneurol.2008.582

Flex, A., Giovannini, S., Biscetti, F., Liperoti, R., Spalletta, G., Straface, G., et al. (2014). Effect of proinflammatory gene polymorphisms on the risk of Alzheimer's disease. Neurodegener. Dis. 13, 230-236. doi: 10.1159/000353395

Flynn, G., Maru, S., Loughlin, J., Romero, I. A., and Male, D. (2003). Regulation of chemokine receptor expression in human microglia and astrocytes. J. Neuroimmunol. 136, 84-93. doi: 10.1016/s0165-5728(03)00009-2

Fontana, L., Eagon, J. C., Trujillo, M. E., Scherer, P. E., and Klein, S. (2007). Visceral fat adipokine secretion is associated with systemic inflammation in obese humans. Diabetes 56, 1010-1013. doi: 10.2337/db06-1656

Gilliver, S. C. (2010). Sex steroids as inflammatory regulators. J. Steroid Biochem. Mol. Biol. 120, 105-115. doi: 10.1016/j.jsbmb.2009.12.015

Golden, S. H., Kim, C., Barrett-Connor, E., Nan, B., Kong, S., Goldberg, R., et al. (2013). The association of elective hormone therapy with changes in lipids among glucose intolerant postmenopausal women in the diabetes prevention program. Metabolism 62, 1313-1322. doi: 10.1016/j.metabol.2013.04.005

Granholm, A. C., Bimonte-Nelson, H. A., Moore, A. B., Nelson, M. E., Freeman, L. R., and Sambamurti, K. (2008). Effects of a saturated fat and high cholesterol diet on memory and hippocampal morphology in the middle-aged rat. J. Alzheimers Dis. 14, 133-145.

Greco, S. J., Sarkar, S., Johnston, J. M., Zhu, X., Su, B., Casadesus, G., et al. (2008). Leptin reduces Alzheimer's disease-related tau phosphorylation in neuronal cells. Biochem. Biophys. Res. Commun. 376, 536-541. doi: 10.1016/j.bbrc.2008. 09.026

Gustafson, D. R., Bäckman, K., Waern, M., Ostling, S., Guo, X., Zandi, P., et al. (2009). Adiposity indicators and dementia over 32, years in Sweden. Neurology 73, 1559-1566. doi: 10.1212/WNL.0b013e3181c0d4b6

Guthrie, J. R., Dennerstein, L., and Dudley, E. C. (1999). Weight gain and the menopause: a 5-year prospective study. Climacteric 2, 205-211. doi: 10. 3109/13697139909038063

Haarbo, J., Marslew, U., Gotfredsen, A., and Christiansen, C. (1991). Postmenopausal hormone replacement therapy prevents central distribution of body fat after menopause. Metabolism 40, 1323-1326. doi: 10.1016/00260495(91)90037-w

Hankinson, S. E., Colditz, G. A., Hunter, D. J., Manson, J. E., Willett, W. C., Stampfer, M. J., et al. (1995). Reproductive factors and family history of breast cancer in relation to plasma estrogen and prolactin levels in postmenopausal women in the Nurses' Health Study (United States). Cancer Causes Control 6, 217-224. doi: 10.1007/bf00051793
Hardy, J. (2006). Alzheimer's disease: the amyloid cascade hypothesis: an update and reappraisal. J. Alzheimers Dis. 9, 151-153.

Hardy, J. A., and Higgins, G. A. (1992). Alzheimer's disease: the amyloid cascade hypothesis. Science 256, 184-185. doi: 10.1126/science.1566067

Harold, D., Abraham, R., Hollingworth, P., Sims, R., Gerrish, A., Hamshere, M. L., et al. (2009). Genome-wide association study identifies variants at CLU and PICALM associated with Alzheimer's disease. Nat. Genet. 41, 1088-1093. doi: 10.1038/ng.440

Hassing, L. B., Hofer, S. M., Nilsson, S. E., Berg, S., Pedersen, N. L., McClearn, G., et al. (2004). Comorbid type 2, diabetes mellitus and hypertension exacerbates cognitive decline: evidence from a longitudinal study. Age Ageing 33, 355-361. doi: 10.1093/ageing/afh100

He, P., Zhong, Z., Lindholm, K., Berning, L., Lee, W., Lemere, C., et al. (2007). Deletion of tumor necrosis factor death receptor inhibits amyloid beta generation and prevents learning and memory deficits in Alzheimer's mice. J. Cell Biol. 178, 829-841. doi: 10.1083/jcb.200705042

Heine, P. A., Taylor, J. A., Iwamoto, G. A., Lubahn, D. B., and Cooke, P. S. (2000). Increased adipose tissue in male and female estrogen receptor-alpha knockout mice. Proc. Natl. Acad. Sci. U S A 97, 12729-12734. doi: 10.1073/pnas.97.23. 12729

Henderson, V. W., Benke, K. S., Green, R. C., Cupples, L. A., Farrer, L. A., and Group, M. S. (2005). Postmenopausal hormone therapy and Alzheimer's disease risk: interaction with age. J. Neurol. Neurosurg. Psychiatry 76, 103-105. doi: 10.1136/jnnp.2003.024927

Henderson, V. W., Paganini-Hill, A., Emanuel, C. K., Dunn, M. E., and Buckwalter, J. G. (1994). Estrogen replacement therapy in older women. Comparisons between Alzheimer's disease cases and nondemented control subjects. Arch. Neurol. 51, 896-900. doi: 10.1001/archneur.1994. 00540210068014

Henderson, V. W., Watt, L., and Buckwalter, J. G. (1996). Cognitive skills associated with estrogen replacement in women with Alzheimer's disease. Psychoneuroendocrinology 21, 421-430. doi: 10.1016/0306-4530(95) 00060-7

Herculano, B., Tamura, M., Ohba, A., Shimatani, M., Kutsuna, N., and Hisatsune, T. (2013). beta-alanyl-L-histidine rescues cognitive deficits caused by feeding a high fat diet in a transgenic mouse model of Alzheimer's disease. J. Alzheimers Dis. 33, 983-997. doi: 10.3233/JAD-2012-121324

Ho, S. C., Wu, S., Chan, S. G., and Sham, A. (2010). Menopausal transition and changes of body composition: a prospective study in Chinese perimenopausal women. Int. J. Obes. (Lond) 34, 1265-1274. doi: 10.1038/ijo. 2010.33

Hollingworth, P., Harold, D., Sims, R., Gerrish, A., Lambert, J. C., Carrasquillo, M. M., et al. (2011). Common variants at ABCA7, MS4A6A/MS4A4E, EPHA1, CD33 and CD2AP are associated with Alzheimer's disease. Nat. Genet. 43, 429-435. doi: 10.1038/ng.803

Hotamisligil, G. S. (2006). Inflammation and metabolic disorders. Nature 444, 860-867. doi: 10.1038/nature05485

Hotamisligil, G. S., Arner, P., Caro, J. F., Atkinson, R. L., and Spiegelman, B. M. (1995). Increased adipose tissue expression of tumor necrosis factor-alpha in human obesity and insulin resistance. J. Clin. Invest. 95, 2409-2415. doi: 10. 1172/jci117936

Hotamisligil, G. S., Shargill, N. S., and Spiegelman, B. M. (1993). Adipose expression of tumor necrosis factor-alpha: direct role in obesity-linked insulin resistance. Science 259, 87-91. doi: 10.1126/science.7678183

Hsu, T. M., Konanur, V. R., Taing, L., Usui, R., Kayser, B. D., Goran, M. I., et al. (2015). Effects of sucrose and high fructose corn syrup consumption on spatial memory function and hippocampal neuroinflammation in adolescent rats. Hippocampus 25, 227-239. doi: 10.1002/hipo.22368

Hwang, L. L., Wang, C. H., Li, T. L., Chang, S. D., Lin, L. C., Chen, C. P., et al. (2010). Sex differences in high-fat diet-induced obesity, metabolic alterations and learning and synaptic plasticity deficits in mice. Obesity (Silver Spring) 18, 463-469. doi: 10.1038/oby.2009.273

Imtiaz, B., Tuppurainen, M., Tiihonen, M., Kivipelto, M., Soininen, H., Hartikainen, S., et al. (2014). Oophorectomy, hysterectomy and risk of Alzheimer's disease: a nationwide case-control study. J. Alzheimers Dis. 42, 575-581. doi: 10.3233/JAD-140336

Iqbal, K., Liu, F., Gong, C. X., and Grundke-Iqbal, I. (2010). Tau in Alzheimer disease and related tauopathies. Curr. Alzheimer Res. 7, 656-664. doi: 10 2174/156720510793611592 
Islander, U., Jochems, C., Lagerquist, M. K., Forsblad-d'Elia, H., and Carlsten, H. (2011). Estrogens in rheumatoid arthritis; the immune system and bone. Mol. Cell. Endocrinol. 335, 14-29. doi: 10.1016/j.mce.2010.05.018

Janssen, I., Powell, L. H., Crawford, S., Lasley, B., and Sutton-Tyrrell, K. (2008). Menopause and the metabolic syndrome: the study of women's health across the nation. Arch. Intern. Med. 168, 1568-1575. doi: 10.1001/archinte.168.14. 1568

Jayaraman, A., Lent-Schochet, D., and Pike, C. J. (2014). Diet-induced obesity and low testosterone increase neuroinflammation and impair neural function. J. Neuroinflammation 11:162. doi: 10.1186/s12974-014-0162-y

Jayaraman, A., and Pike, C. J. (2014). Alzheimer's disease and type 2, diabetes: multiple mechanisms contribute to interactions. Curr. Diab. Rep. 14:476. doi: 10.1007/s11892-014-0476-2

Jimenez, S., Baglietto-Vargas, D., Caballero, C., Moreno-Gonzalez, I., Torres, M., Sanchez-Varo, R., et al. (2008). Inflammatory response in the hippocampus of PS1M146L/APP751SL mouse model of Alzheimer's disease: age-dependent switch in the microglial phenotype from alternative to classic. J. Neurosci. 28, 11650-11661. doi: 10.1523/JNEUROSCI.3024-08.2008

Johnston, H., Boutin, H., and Allan, S. M. (2011). Assessing the contribution of inflammation in models of Alzheimer's disease. Biochem. Soc. Trans. 39, 886-890. doi: 10.1042/BST0390886

Johnston, J. M., Hu, W. T., Fardo, D. W., Greco, S. J., Perry, G., Montine, T. J., et al. (2014). Low plasma leptin in cognitively impaired ADNI subjects: gender differences and diagnostic and therapeutic potential. Curr. Alzheimer Res. 11, 165-174. doi: 10.2174/1567205010666131212114156

Jones, M. E., Thorburn, A. W., Britt, K. L., Hewitt, K. N., Wreford, N. G., Proietto, J., et al. (2000). Aromatase-deficient (ArKO) mice have a phenotype of increased adiposity. Proc. Natl. Acad. Sci. U S A 97, 12735-12740. doi: 10. 1073/pnas.97.23.12735

Julien, C., Tremblay, C., Phivilay, A., Berthiaume, L., Emond, V., Julien, P., et al. (2010). High-fat diet aggravates amyloid-beta and tau pathologies in the 3xTg-AD mouse model. Neurobiol. Aging 31, 1516-1531. doi: 10.1016/j. neurobiolaging.2008.08.022

Karran, E., Mercken, M., and De Strooper, B. (2011). The amyloid cascade hypothesis for Alzheimer's disease: an appraisal for the development of therapeutics. Nat. Rev. Drug Discov. 10, 698-712. doi: 10.1038/nrd3505

Kawas, C., Resnick, S., Morrison, A., Brookmeyer, R., Corrada, M., Zonderman, A., et al. (1997). A prospective study of estrogen replacement therapy and the risk of developing Alzheimer's disease: the Baltimore longitudinal study of aging. Neurology 48, 1517-1521. doi: 10.1212/wnl.48.6.1517

Kern, P. A., Ranganathan, S., Li, C., Wood, L., and Ranganathan, G. (2001). Adipose tissue tumor necrosis factor and interleukin-6 expression in human obesity and insulin resistance. Am. J. Physiol. Endocrinol. Metab. 280, E745-E751.

Kim, B., and Feldman, E. L. (2015). Insulin resistance as a key link for the increased risk of cognitive impairment in the metabolic syndrome. Exp. Mol. Med. 47:e149. doi: 10.1038/emm.2015.3

Kissebah, A. H., Vydelingum, N., Murray, R., Evans, D. J., Hartz, A. J., Kalkhoff, R. K., et al. (1982). Relation of body fat distribution to metabolic complications of obesity. J. Clin Endocrinol Metab 54, 254-260. doi: 10.1210/jcem-54-2-254

Kivipelto, M., Ngandu, T., Fratiglioni, L., Viitanen, M., Kåreholt, I., Winblad, B., et al. (2005). Obesity and vascular risk factors at midlife and the risk of dementia and Alzheimer disease. Arch. Neurol. 62, 1556-1560. doi: 10.1001/archneur.62. 10.1556

Knowlton, A. A., and Lee, A. R. (2012). Estrogen and the cardiovascular system. Pharmacol. Ther. 135, 54-70. doi: 10.1016/j.pharmthera.2012.03.007

Koenigsknecht-Talboo, J., and Landreth, G. E. (2005). Microglial phagocytosis induced by fibrillar beta-amyloid and IgGs are differentially regulated by proinflammatory cytokines. J. Neurosci. 25, 8240-8249. doi: 10.1523/jneurosci. 1808-05.2005

Kristensen, K., Pedersen, S. B., Vestergaard, P., Mosekilde, L., and Richelsen, B. (1999). Hormone replacement therapy affects body composition and leptin differently in obese and non-obese postmenopausal women. J. Endocrinol. 163, 55-62. doi: 10.1677/joe.0.1630055

LaFerla, F. M. (2010). Pathways linking Abeta and tau pathologies. Biochem. Soc. Trans. 38, 993-995. doi: 10.1042/BST0380993

Lambert, J. C., Heath, S., Even, G., Campion, D., Sleegers, K., Hiltunen, M., et al. (2009). Genome-wide association study identifies variants at CLU and
CR1 associated with Alzheimer's disease. Nat. Genet. 41, 1094-1099. doi: 10. 1038/ng.439

Leavy, O. (2015). Neuroimmunology: TREM2 in Alzheimer disease. Nat. Rev. Immunol. 15:201. doi: 10.1038/nri3842

Leduc, V., Domenger, D., De Beaumont, L., Lalonde, D., Belanger-Jasmin, S., and Poirier, J. (2011). Function and comorbidities of apolipoprotein e in Alzheimer's disease. Int. J. Alzheimers Dis. 2011:974361. doi: 10. 4061/2011/974361

Lewis, D. K., Bake, S., Thomas, K., Jezierski, M. K., and Sohrabji, F. (2010). A high cholesterol diet elevates hippocampal cytokine expression in an age and estrogen-dependent manner in female rats. J. Neuroimmunol. 223, 31-38. doi: 10.1016/j.jneuroim.2010.03.024

Li, R., Strohmeyer, R., Liang, Z., Lue, L. F., and Rogers, J. (2004). CCAAT/enhancer binding protein delta (C/EBPdelta) expression and elevation in Alzheimer's disease. Neurobiol. Aging 25, 991-999. doi: 10.1016/j.neurobiolaging.2003.10. 016

Lieb, W., Beiser, A. S., Vasan, R. S., Tan, Z. S., Au, R., Harris, T. B., et al. (2009). Association of plasma leptin levels with incident Alzheimer disease and MRI measures of brain aging. JAMA 302, 2565-2572. doi: 10.1001/jama.2009.1836

López, S., Bermúdez, B., Pacheco, Y. M., Villar, J., Abia, R., and Muriana, F. J. (2008). Distinctive postprandial modulation of beta cell function and insulin sensitivity by dietary fats: monounsaturated compared with saturated fatty acids. Am. J. Clin. Nutr. 88, 638-644.

Lord, G. M., Matarese, G., Howard, J. K., Baker, R. J., Bloom, S. R., and Lechler, R. I. (1998). Leptin modulates the T-cell immune response and reverses starvationinduced immunosuppression. Nature 394, 897-901. doi: 10.1038/29795

Luchsinger, J. A., Cheng, D., Tang, M. X., Schupf, N., and Mayeux, R. (2012). Central obesity in the elderly is related to late-onset Alzheimer disease. Alzheimer Dis. Assoc. Disord. 26, 101-105. doi: 10.1097/WAD. 0b013e318222fod4

Luchsinger, J. A., Tang, M. X., Shea, S., and Mayeux, R. (2004). Hyperinsulinemia and risk of Alzheimer disease. Neurology 63, 1187-1192. doi: 10.1212/01.wnl. 0000140292.04932 .87

Maioli, S., Lodeiro, M., Merino-Serrais, P., Falahati, F., Khan, W., Puerta, E., et al. (2015). Alterations in brain leptin signalling in spite of unchanged CSF leptin levels in Alzheimer's disease. Aging Cell 14, 122-129. doi: 10.1111/acel.12281

Maki, P. M. (2006). Potential importance of early initiation of hormone therapy for cognitive benefit. Menopause 13, 6-7. doi: 10.1097/01.gme.0000194822. 76774.30

Mandrekar-Colucci, S., and Landreth, G. E. (2010). Microglia and inflammation in Alzheimer's disease. CNS Neurol. Disord. Drug Targets 9, 156-167. doi: 10. 2174/187152710791012071

Manly, J. J., Merchant, C. A., Jacobs, D. M., Small, S. A., Bell, K., Ferin, M., et al. (2000). Endogenous estrogen levels and Alzheimer's disease among postmenopausal women. Neurology 54, 833-837. doi: 10.1212/wnl.54.4.833

Martín-Millán, M., and Castañeda, S. (2013). Estrogens, osteoarthritis and inflammation. Joint Bone Spine 80, 368-373. doi: 10.1016/j.jbspin.2012.11.008

Martín-Romero, C., Santos-Alvarez, J., Goberna, R., and Sánchez-Margalet, V. (2000). Human leptin enhances activation and proliferation of human circulating T lymphocytes. Cell Immunol. 199, 15-24. doi: 10.1006/cimm.1999. 1594

McGill, A. T. (2014). Past and future corollaries of theories on causes of metabolic syndrome and obesity related co-morbidities part 2: a composite unifying theory review of human-specific co-adaptations to brain energy consumption. Arch. Public Health 72:31. doi: 10.1186/2049-3258-72-31

McLay, R. N., Maki, P. M., and Lyketsos, C. G. (2003). Nulliparity and late menopause are associated with decreased cognitive decline. J. Neuropsychiatry Clin. Neurosci. 15, 161-167. doi: 10.1176/appi.neuropsych.15.2.161

Meda, L., Cassatella, M. A., Szendrei, G. I., Otvos, L. Jr., Baron, P., Villalba, M., et al. (1995). Activation of microglial cells by beta-amyloid protein and interferon-gamma. Nature 374, 647-650. doi: 10.1038/374647a0

Meyer, M. R., Clegg, D. J., Prossnitz, E. R., and Barton, M. (2011). Obesity, insulin resistance and diabetes: sex differences and role of oestrogen receptors. Acta Physiol. (Oxf.) 203, 259-269. doi: 10.1111/j.1748-1716.2010.02237.x

Meyer-Luehmann, M., Spires-Jones, T. L., Prada, C., Garcia-Alloza, M., de Calignon, A., Rozkalne, A., et al. (2008). Rapid appearance and local toxicity of amyloid-beta plaques in a mouse model of Alzheimer's disease. Nature 451, 720-724. doi: 10.1038/nature06616 
Michaud, M., Balardy, L., Moulis, G., Gaudin, C., Peyrot, C., Vellas, B., et al. (2013). Proinflammatory cytokines, aging and age-related diseases. J. Am. Med. Dir. Assoc. 14, 877-882. doi: 10.1016/j.jamda.2013.05.009

Milanski, M., Degasperi, G., Coope, A., Morari, J., Denis, R., Cintra, D. E., et al. (2009). Saturated fatty acids produce an inflammatory response predominantly through the activation of TLR4 signaling in hypothalamus: implications for the pathogenesis of obesity. J. Neurosci. 29, 359-370. doi: 10.1523/JNEUROSCI. 2760-08.2009

Molteni, R., Barnard, R. J., Ying, Z., Roberts, C. K., and Gómez-Pinilla, F. (2002). A high-fat, refined sugar diet reduces hippocampal brain-derived neurotrophic factor, neuronal plasticity and learning. Neuroscience 112, 803-814. doi: 10 . 1016/s0306-4522(02)00123-9

Morris, G. P., Clark, I. A., and Vissel, B. (2014). Inconsistencies and controversies surrounding the amyloid hypothesis of Alzheimer's disease. Acta Neuropathol. Commun. 2:135. doi: 10.1186/s40478-014-0135-5

Mosconi, L. (2005). Brain glucose metabolism in the early and specific diagnosis of Alzheimer's disease. FDG-PET studies in MCI and AD. Eur. J. Nucl. Med. Mol. Imaging 32, 486-510. doi: 10.1007/s00259-005-1762-7

Mosconi, L., Pupi, A., and De Leon, M. J. (2008). Brain glucose hypometabolism and oxidative stress in preclinical Alzheimer's disease. Ann. NY Acad. Sci. 1147, 180-195. doi: 10.1196/annals.1427.007

Mrak, R. E., and Griffin, W. S. (2005). Glia and their cytokines in progression of neurodegeneration. Neurobiol. Aging 26, 349-354. doi: 10. 1016/j.neurobiolaging.2004.05.010

Mucke, L., and Selkoe, D. J. (2012). Neurotoxicity of amyloid beta-protein: synaptic and network dysfunction. Cold Spring Harb. Perspect. Med. 2:a006338. doi: 10.1101/cshperspect.a006338

Murray, A. J., Knight, N. S., Cochlin, L. E., McAleese, S., Deacon, R. M., Rawlins, J. N., et al. (2009). Deterioration of physical performance and cognitive function in rats with short-term high-fat feeding. FASEB J. 23, 4353-4360. doi: 10.1096/fj.09-139691

Naj, A. C., Jun, G., Beecham, G. W., Wang, L. S., Vardarajan, B. N., Buros, J., et al. (2011). Common variants at MS4A4/MS4A6E, CD2AP, CD33 and EPHA1 are associated with late-onset Alzheimer's disease. Nat. Genet. 43, 436-441. doi: 10. 1038/ng.801

Näslund, J., Thyberg, J., Tjernberg, L. O., Wernstedt, C., Karlstrom, A. R., Bogdanovic, N., et al. (1995). Characterization of stable complexes involving apolipoprotein $\mathrm{E}$ and the amyloid beta peptide in Alzheimer's disease brain. Neuron 15, 219-228. doi: 10.1016/0896-6273(95) 90079-9

Nieves, D. J., Cnop, M., Retzlaff, B., Walden, C. E., Brunzell, J. D., Knopp, R. H., et al. (2003). The atherogenic lipoprotein profile associated with obesity and insulin resistance is largely attributable to intra-abdominal fat. Diabetes 52, 172-179. doi: 10.2337/diabetes.52.1.172

Nordell, V. L., Scarborough, M. M., Buchanan, A. K., and Sohrabji, F. (2003). Differential effects of estrogen in the injured forebrain of young adult and reproductive senescent animals. Neurobiol. Aging 24, 733-743. doi: 10. 1016/s0197-4580(02)00193-8

Ogden, C. L., Carroll, M. D., Kit, B. K., and Flegal, K. M. (2014). Prevalence of childhood and adult obesity in the United States, 2011-2012. JAMA 311, 806-814. doi: 10.1001/jama.2014.732

Orr, M. E., Salinas, A., Buffenstein, R., and Oddo, S. (2014). Mammalian target of rapamycin hyperactivity mediates the detrimental effects of a high sucrose diet on Alzheimer's disease pathology. Neurobiol. Aging 35, 1233-1242. doi: 10. 1016/j.neurobiolaging.2013.12.006

Papassotiropoulos, A., Bagli, M., Jessen, F., Bayer, T. A., Maier, W., Rao, M. L., et al. (1999). A genetic variation of the inflammatory cytokine interleukin-6 delays the initial onset and reduces the risk for sporadic Alzheimer's disease. Ann. Neurol. 45, 666-668. doi: 10.1002/1531-8249(199905)45:5<666::aid-ana18>3. $0 . \operatorname{co} ; 2-3$

Park, H. K., and Ahima, R. S. (2015). Physiology of leptin: energy homeostasis, neuroendocrine function and metabolism. Metabolism 64, 24-34. doi: 10. 1016/j.metabol.2014.08.004

Parkhurst, C. N., Yang, G., Ninan, I., Savas, J. N., Yates, J. R. IIII, Lafaille, J. J., et al. (2013). Microglia promote learning-dependent synapse formation through brain-derived neurotrophic factor. Cell 155, 1596-1609. doi: 10.1016/j. cell.2013.11.030

Patsouris, D., Li, P. P., Thapar, D., Chapman, J., Olefsky, J. M., and Neels, J. G. (2008). Ablation of CD11c-positive cells normalizes insulin sensitivity in obese insulin resistant animals. Cell Metab. 8, 301-309. doi: 10.1016/j.cmet. 2008.08.015

Payami, H., Zareparsi, S., Montee, K. R., Sexton, G. J., Kaye, J. A., Bird, T. D., et al. (1996). Gender difference in apolipoprotein E-associated risk for familial Alzheimer disease: a possible clue to the higher incidence of Alzheimer disease in women. Am. J. Hum. Genet. 58, 803-811.

Pfeilschifter, J., Köditz, R., Pfohl, M., and Schatz, H. (2002). Changes in proinflammatory cytokine activity after menopause. Endocr. Rev. 23, 90-119. doi: 10.1210/er.23.1.90

Phung, T. K., Waltoft, B. L., Laursen, T. M., Settnes, A., Kessing, L. V., Mortensen, P. B., et al. (2010). Hysterectomy, oophorectomy and risk of dementia: a nationwide historical cohort study. Dement. Geriatr. Cogn. Disord. 30, 43-50. doi: 10.1159/000314681

Pike, C. J., Carroll, J. C., Rosario, E. R., and Barron, A. M. (2009). Protective actions of sex steroid hormones in Alzheimer's disease. Front. Neuroendocrinol. 30, 239-258. doi: 10.1016/j.yfrne.2009.04.015

Plutzky, J. (2001). Inflammatory pathways in atherosclerosis and acute coronary syndromes. Am. J. Cardiol. 88, 10K-15K. doi: 10.1016/s0002-9149(01)01924-5

Poehlman, E. T., Toth, M. J., and Gardner, A. W. (1995). Changes in energy balance and body composition at menopause: a controlled longitudinal study. Ann. Intern. Med. 123, 673-675. doi: 10.7326/0003-4819-123-9-19951101000005

Pradhan, A. D., Manson, J. E., Rifai, N., Buring, J. E., and Ridker, P. M. (2001). Creactive protein, interleukin 6 and risk of developing type 2, diabetes mellitus. JAMA 286, 327-334. doi: 10.1001/jama.286.3.327

Profenno, L. A., Porsteinsson, A. P., and Faraone, S. V. (2010). Meta-analysis of Alzheimer's disease risk with obesity, diabetes and related disorders. Biol. Psychiatry 67, 505-512. doi: 10.1016/j.biopsych.2009.02.013

Prokop, S., Miller, K. R., and Heppner, F. L. (2013). Microglia actions in Alzheimer's disease. Acta Neuropathol. 126, 461-477. doi: 10.1007/s00401-0131182-X

Ptok, U., Barkow, K., and Heun, R. (2002). Fertility and number of children in patients with Alzheimer's disease. Arch. Womens Ment. Health. 5, 83-86. doi: 10.1007/s00737-002-0142-6

Qizilbash, N., Gregson, J., Johnson, M. E., Pearce, N., Douglas, I., Wing, K., et al. (2015). BMI and risk of dementia in two million people over two decades: a retrospective cohort study. Lancet Diabetes Endocrinol. 3, 431-436. doi: 10. 1016/s2213-8587(15)00033-9

Quintanilla, R. A., Orellana, D. I., González-Billault, C., and Maccioni, R. B. (2004). Interleukin-6 induces Alzheimer-type phosphorylation of tau protein by deregulating the cdk5/p35 pathway. Exp. Cell Res. 295, 245-257. doi: 10. 1016/j.yexcr.2004.01.002

Rachoń, D., and Teede, H. (2010). Ovarian function and obesity-interrelationship, impact on women's reproductive lifespan and treatment options. Mol. Cell. Endocrinol. 316, 172-179. doi: 10.1016/j.mce. 2009.09.026

Rahmouni, K. (2014). Obesity-associated hypertension: recent progress in deciphering the pathogenesis. Hypertension 64, 215-221. doi: 10. 1161/hypertensionaha.114.00920

Raso, G. M., Pacilio, M., Esposito, E., Coppola, A., Di Carlo, R., and Meli, R. (2002). Leptin potentiates IFN-gamma-induced expression of nitric oxide synthase and cyclo-oxygenase-2 in murine macrophage J774A.1. Br. J. Pharmacol. 137, 799-804. doi: 10.1038/sj.bjp.0704903

Reger, M. A., Watson, G. S., Green, P. S., Wilkinson, C. W., Baker, L. D., Cholerton, B., et al. (2008). Intranasal insulin improves cognition and modulates beta-amyloid in early AD. Neurology 70, 440-448. doi: 10.1212/01. WNL.0000265401.62434.36

Rocca, W. A., Bower, J. H., Maraganore, D. M., Ahlskog, J. E., Grossardt, B. R., de Andrade, M., et al. (2007). Increased risk of cognitive impairment or dementia in women who underwent oophorectomy before menopause. Neurology 69, 1074-1083. doi: 10.1212/01.wnl.0000276984.19542.e6

Rocca, W. A., Grossardt, B. R., and Shuster, L. T. (2011). Oophorectomy, menopause, estrogen treatment and cognitive aging: clinical evidence for a window of opportunity. Brain Res. 1379, 188-198. doi: 10.1016/j.brainres.2010. 10.031

Rocha, V. Z., and Libby, P. (2009). Obesity, inflammation and atherosclerosis. Nat. Rev. Cardiol. 6, 399-409. doi: 10.1038/nrcardio.2009.55

Rogers, N. H., Perfield, J. W. 2nd, Strissel, K. J., Obin, M. S., and Greenberg, A. S. (2009). Reduced energy expenditure and increased inflammation are early 
events in the development of ovariectomy-induced obesity. Endocrinology 150, 2161-2168. doi: 10.1210/en.2008-1405

Rosario, E. R., Chang, L., Head, E. H., Stanczyk, F. Z., and Pike, C. J. (2011). Brain levels of sex steroid hormones in men and women during normal aging and in Alzheimer's disease. Neurobiol. Aging 32, 604-613. doi: 10.1016/j. neurobiolaging.2009.04.008

Ryan, E. A., and Enns, L. (1988). Role of gestational hormones in the induction of insulin resistance. J. Clin. Endocrinol. Metab. 67, 341-347. doi: 10.1210/jcem67-2-341

Salpeter, S. R., Walsh, J. M., Ormiston, T. M., Greyber, E., Buckley, N. S., and Salpeter, E. E. (2006). Meta-analysis: effect of hormone-replacement therapy on components of the metabolic syndrome in postmenopausal women. Diabetes Obes. Metab. 8, 538-554. doi: 10.1111/j.1463-1326.2005.00545.x

Santos-Alvarez, J., Goberna, R., and Sánchez-Margalet, V. (1999). Human leptin stimulates proliferation and activation of human circulating monocytes. Cell. Immunol. 194, 6-11. doi: 10.1006/cimm.1999.1490

Sárvári, M., Hrabovszky, E., Kalló, I., Solymosi, N., Likó, I., Berchtold, N., et al. (2012). Menopause leads to elevated expression of macrophage-associated genes in the aging frontal cortex: rat and human studies identify strikingly similar changes. J. Neuroinflammation 9:264. doi: 10.1186/1742-2094-9-264

Sárvári, M., Hrabovszky, E., Kalló, I., Solymosi, N., Tóth, K., Likó, I., et al. (2011). Estrogens regulate neuroinflammatory genes via estrogen receptors alpha and beta in the frontal cortex of middle-aged female rats. J. Neuroinflammation 8:82. doi: 10.1186/1742-2094-8-82

Senn, J. J., Klover, P. J., Nowak, I. A., and Mooney, R. A. (2002). Interleukin6 induces cellular insulin resistance in hepatocytes. Diabetes 51, 3391-3399. doi: 10.2337/diabetes.51.12.3391

Shao, H., Breitner, J. C., Whitmer, R. A., Wang, J., Hayden, K., Wengreen, H., et al. (2012). Hormone therapy and Alzheimer disease dementia: new findings from the Cache County Study. Neurology 79, 1846-1852. doi: 10.1212/WNL. 0b013e318271f823

Shumaker, S. A., Legault, C., Kuller, L., Rapp, S. R., Thal, L., Lane, D. S., et al. (2004). Conjugated equine estrogens and incidence of probable dementia and mild cognitive impairment in postmenopausal women: women's health initiative memory study. JAMA 291, 2947-2958. doi: 10.1001/jama.291. 24.2947

Shumaker, S. A., Legault, C., Rapp, S. R., Thal, L., Wallace, R. B., Ockene, J. K., et al. (2003). Estrogen plus progestin and the incidence of dementia and mild cognitive impairment in postmenopausal women: the women's health initiative memory study: a randomized controlled trial. JAMA 289, 2651-2662. doi: 10. 1001/jama.289.20.2651

Singh-Manoux, A., Dugravot, A., Brunner, E., Kumari, M., Shipley, M., Elbaz, A., et al. (2014). Interleukin-6 and C-reactive protein as predictors of cognitive decline in late midlife. Neurology 83, 486-493. doi: 10.1212/wnl. 0000000000000665

Sites, C. K., Calles-Escandon, J., Brochu, M., Butterfield, M., Ashikaga, T., and Poehlman, E. T. (2000). Relation of regional fat distribution to insulin sensitivity in postmenopausal women. Fertil. Steril. 73, 61-65. doi: 10. 1016/s0015-0282(99)00453-7

Sternfeld, B., Wang, H., Quesenberry, C. P. Jr., Abrams, B., Everson-Rose, S. A., Greendale, G. A., et al. (2004). Physical activity and changes in weight and waist circumference in midlife women: findings from the study of women's health across the nation. Am. J. Epidemiol. 160, 912-922. doi: 10.1093/aje/kwh299

Straub, R. H. (2007). The complex role of estrogens in inflammation. Endocr. Rev. 28, 521-574. doi: 10.1210/er.2007-0001

Stubbins, R. E., Holcomb, V. B., Hong, J., and Nunez, N. P. (2012). Estrogen modulates abdominal adiposity and protects female mice from obesity and impaired glucose tolerance. Eur. J. Nutr. 51, 861-870. doi: 10.1007/s00394-0110266-4

Suh, H. S., Zhao, M. L., Derico, L., Choi, N., and Lee, S. C. (2013). Insulin-like growth factor 1 and 2, (IGF1, IGF2) expression in human microglia: differential regulation by inflammatory mediators. J. Neuroinflammation 10:37. doi: 10 . 1186/1742-2094-10-37

Takalo, M., Haapasalo, A., Martiskainen, H., Kurkinen, K. M., Koivisto, H., Miettinen, P., et al. (2014). High-fat diet increases tau expression in the brain of T2DM and AD mice independently of peripheral metabolic status. J. Nutr. Biochem. 25, 634-641. doi: 10.1016/j.jnutbio.2014.02.003

Takeda, S., Sato, N., Ikimura, K., Nishino, H., Rakugi, H., and Morishita, R. (2013). Increased blood-brain barrier vulnerability to systemic inflammation in an Alzheimer disease mouse model. Neurobiol. Aging 34, 2064-2070. doi: 10. 1016/j.neurobiolaging.2013.02.010

Takeda, S., Sato, N., Uchio-Yamada, K., Sawada, K., Kunieda, T., Takeuchi, D., et al. (2010). Diabetes-accelerated memory dysfunction via cerebrovascular inflammation and Abeta deposition in an Alzheimer mouse model with diabetes. Proc. Natl. Acad. Sci. U S A 107, 7036-7041. doi: 10.3410/f.2820960. 2486058

Tang, M. X., Jacobs, D., Stern, Y., Marder, K., Schofield, P., Gurland, B., et al. (1996). Effect of oestrogen during menopause on risk and age at onset of Alzheimer's disease. Lancet 348, 429-432. doi: 10.1016/s0140-6736(96) 03356-9

Tanzi, R. E. (2012). The genetics of Alzheimer disease. Cold Spring Harb. Perspect. Med. 2:a006296. doi: 10.1101/cshperspect.a006296

Tchernof, A., Calles-Escandon, J., Sites, C. K., and Poehlman, E. T. (1998). Menopause, central body fatness and insulin resistance: effects of hormonereplacement therapy. Coron. Artery Dis. 9, 503-511. doi: 10.1097/00019501199809080-00006

Teeling, J. L., and Perry, V. H. (2009). Systemic infection and inflammation in acute CNS injury and chronic neurodegeneration: underlying mechanisms. Neuroscience 158, 1062-1073. doi: 10.1016/j.neuroscience.2008.07.031

Thaler, J. P., Guyenet, S. J., Dorfman, M. D., Wisse, B. E., and Schwartz, M. W. (2013). Hypothalamic inflammation: marker or mechanism of obesity pathogenesis? Diabetes 62, 2629-2634. doi: 10.2337/db12-1605

Thaler, J. P., and Schwartz, M. W. (2010). Minireview: inflammation and obesity pathogenesis: the hypothalamus heats up. Endocrinology 151, 4109-4115. doi: 10.1210/en.2010-0336

Thaler, J. P., Yi, C. X., Schur, E. A., Guyenet, S. J., Hwang, B. H., Dietrich, M. O., et al. (2012). Obesity is associated with hypothalamic injury in rodents and humans. J. Clin. Invest. 122, 153-162. doi: 10.1172/JCI59660

Tsigos, C., Kyrou, I., Chala, E., Tsapogas, P., Stavridis, J. C., Raptis, S. A., et al. (1999). Circulating tumor necrosis factor alpha concentrations are higher in abdominal versus peripheral obesity. Metabolism 48, 1332-1335. doi: 10. 1016/s0026-0495(99)90277-9

Tucsek, Z., Toth, P., Sosnowska, D., Gautam, T., Mitschelen, M., Koller, A., et al. (2014). Obesity in aging exacerbates blood-brain barrier disruption, neuroinflammation and oxidative stress in the mouse hippocampus: effects on expression of genes involved in beta-amyloid generation and Alzheimer's disease. J. Gerontol. A Biol. Sci. Med. Sci. 69, 1212-1226. doi: 10. 1093/gerona/glt177

Vandanmagsar, B., Youm, Y. H., Ravussin, A., Galgani, J. E., Stadler, K., Mynatt, R. L., et al. (2011). The NLRP3 inflammasome instigates obesity-induced inflammation and insulin resistance. Nat. Med. 17, 179-188. doi: 10.1038/nm. 2279

Verri, M., Pastoris, O., Dossena, M., Aquilani, R., Guerriero, F., Cuzzoni, G., et al. (2012). Mitochondrial alterations, oxidative stress and neuroinflammation in Alzheimer's disease. Int. J. Immunopathol. Pharmacol. 25, 345-353.

Wajchenberg, B. L. (2000). Subcutaneous and visceral adipose tissue: their relation to the metabolic syndrome. Endocr. Rev. 21, 697-738. doi: 10.1210/er.21.6.697

Wallenius, V., Wallenius, K., Ahren, B., Rudling, M., Carlsten, H., Dickson, S. L., et al. (2002). Interleukin-6-deficient mice develop mature-onset obesity. Nat. Med. 8, 75-79. doi: 10.1038/nm0102-75

Weisberg, S. P., McCann, D., Desai, M., Rosenbaum, M., Leibel, R. L., Ferrante, A. W. Jr., et al. (2003). Obesity is associated with macrophage accumulation in adipose tissue. J. Clin. Invest. 112, 1796-1808. doi: 10.1172/jci200319246

Whitmer, R. A., Gustafson, D. R., Barrett-Connor, E., Haan, M. N., Gunderson, E. P., and Yaffe, K. (2008). Central obesity and increased risk of dementia more than three decades later. Neurology 71, 1057-1064. doi: 10.1212/01.wnl. 0000306313.89165.ef

Whitmer, R. A., Quesenberry, C. P., Zhou, J., and Yaffe, K. (2011). Timing of hormone therapy and dementia: the critical window theory revisited. Ann. Neurol. 69, 163-169. doi: 10.1002/ana.22239

Wildman, R. P., Tepper, P. G., Crawford, S., Finkelstein, J. S., Sutton-Tyrrell, K., Thurston, R. C., et al. (2012). Do changes in sex steroid hormones precede or follow increases in body weight during the menopause transition? Results from the study of women's health across the nation. J. Clin. Endocrinol. Metab. 97, E1695-E1704. doi: 10.1210/jc.2012-1614

Wyss-Coray, T., and Rogers, J. (2012). Inflammation in Alzheimer disease-a brief review of the basic science and clinical literature. Cold Spring Harb. Perspect. Med. 2:a006346. doi: 10.1101/cshperspect.a006346 
Xie, Z., Wei, M., Morgan, T. E., Fabrizio, P., Han, D., Finch, C. E., et al. (2002). Peroxynitrite mediates neurotoxicity of amyloid beta-peptide1-42- and lipopolysaccharide-activated microglia. J. Neurosci. 22, 3484-3492.

Xu, W. L., Atti, A. R., Gatz, M., Pedersen, N. L., Johansson, B., and Fratiglioni, L. (2011). Midlife overweight and obesity increase late-life dementia risk: a population-based twin study. Neurology 76, 1568-1574. doi: 10.1212/WNL. 0b013e3182190d09

Yaffe, K., Blackwell, T., Kanaya, A. M., Davidowitz, N., Barrett-Connor, E., and Krueger, K. (2004). Diabetes, impaired fasting glucose and development of cognitive impairment in older women. Neurology 63, 658-663. doi: 10.1212/01. wnl.0000134666.64593.ba

Yaffe, K., Haan, M., Byers, A., Tangen, C., and Kuller, L. (2000). Estrogen use, APOE and cognitive decline: evidence of gene-environment interaction. Neurology 54, 1949-1954. doi: 10.1212/wnl.54.10.1949

Yamamoto, M., Kiyota, T., Horiba, M., Buescher, J. L., Walsh, S. M., Gendelman, H. E., et al. (2007). Interferon-gamma and tumor necrosis factor-alpha regulate amyloid-beta plaque deposition and beta-secretase expression in Swedish mutant APP transgenic mice. Am. J. Pathol. 170, 680-692. doi: 10.2353/ajpath. 2007.060378

Yao, J., Rettberg, J. R., Klosinski, L. P., Cadenas, E., and Brinton, R. D. (2011). Shift in brain metabolism in late onset Alzheimer's disease: implications for biomarkers and therapeutic interventions. Mol. Aspects Med. 32, 247-257. doi: 10.1016/j.mam.2011.10.005

Yin, F., Yao, J., Sancheti, H., Feng, T., Melcangi, R. C., Morgan, T. E., et al. (2015). The perimenopausal aging transition in the female rat brain: decline in bioenergetic systems and synaptic plasticity. Neurobiol. Aging 36, 2282-2295. doi: 10.1016/j.neurobiolaging.2015.03.013

Yonezawa, R., Wada, T., Matsumoto, N., Morita, M., Sawakawa, K., Ishii, Y., et al. (2012). Central versus peripheral impact of estradiol on the impaired glucose metabolism in ovariectomized mice on a high-fat diet. Am. J. Physiol. Endocrinol. Metab. 303, E445-E456. doi: 10.1152/ajpendo. 00638.2011

Yu, D., Corbett, B., Yan, Y., Zhang, G. X., Reinhart, P., Cho, S. J., et al. (2012). Early cerebrovascular inflammation in a transgenic mouse model of Alzheimer's disease. Neurobiol. Aging 33, 2942-2947. doi: 10.1016/j.neurobiolaging.2012. 02.023
Yue, X., Lu, M., Lancaster, T., Cao, P., Honda, S., Staufenbiel, M., et al. (2005). Brain estrogen deficiency accelerates Abeta plaque formation in an Alzheimer's disease animal model. Proc. Natl. Acad. Sci. U S A 102, 19198-19203. doi: 10. 1073/pnas.0505203102

Yusuf, S., Hawken, S., Ounpuu, S., Bautista, L., Franzosi, M. G., Commerford, P., et al. (2005). Obesity and the risk of myocardial infarction in 27,000 participants from 52, countries: a case-control study. Lancet 366, 1640-1649. doi: 10.1016/S0140-6736(05)67663-5

Zandi, P. P., Carlson, M. C., Plassman, B. L., Welsh-Bohmer, K. A., Mayer, L. S., Steffens, D. C., et al. (2002). Hormone replacement therapy and incidence of Alzheimer disease in older women: the Cache County Study. JAMA 288, 2123-2129. doi: 10.1001/jama.288.17.2123

Zempel, H., and Mandelkow, E. (2014). Lost after translation: missorting of Tau protein and consequences for Alzheimer disease. Trends Neurosci. 37, 721-732. doi: 10.1016/j.tins.2014.08.004

Zhao, L., Yao, J., Mao, Z., Chen, S., Wang, Y., and Brinton, R. D. (2011). 17betaEstradiol regulates insulin-degrading enzyme expression via an ERbeta/PI3$\mathrm{K}$ pathway in hippocampus: relevance to Alzheimer's prevention. Neurobiol. Aging 32, 1949-1963. doi: 10.1016/j.neurobiolaging.2009.12.010

Zheng, H., Xu, H., Uljon, S. N., Gross, R., Hardy, K., Gaynor, J., et al. (2002). Modulation of A(beta) peptides by estrogen in mouse models. J. Neurochem. 80, 191-196. doi: 10.1046/j.0022-3042.2001.00690.x

Zlokovic, B. V. (2011). Neurovascular pathways to neurodegeneration in Alzheimer's disease and other disorders. Nat. Rev. Neurosci. 12, 723-738. doi: $10.1038 / \mathrm{nrn} 3114$

Conflict of Interest Statement: The authors declare that the research was conducted in the absence of any commercial or financial relationships that could be construed as a potential conflict of interest.

Copyright $\odot 2015$ Christensen and Pike. This is an open-access article distributed under the terms of the Creative Commons Attribution License (CC BY). The use, distribution and reproduction in other forums is permitted, provided the original author(s) or licensor are credited and that the original publication in this journal is cited, in accordance with accepted academic practice. No use, distribution or reproduction is permitted which does not comply with these terms. 